NBER WORKING PAPER SERIES

SIZE REALLY DOESN'T MATTER: IN

SEARCH OF A NATIONAL SCALE EFFECT

Andrew K. Rose

Working Paper 12191

http://www.nber.org/papers/w12191

NATIONAL BUREAU OF ECONOMIC RESEARCH
1050 Massachusetts Avenue
Cambridge, MA 02138
April 2006

B.T. Rocca Jr. Professor of International Business, Economic Analysis and Policy Group, Haas School of Business at the University of California, Berkeley, NBER Research Associate, and CEPR Research Fellow. I conducted part of this work in Singapore (a small diverse rich country), and continued it at the IMF (an institution with ten members of population less than Berkeley): I thank INSEAD and the Fund's Research Department for hospitality during the course of this work. For comments, I thank: an anonymous referee, Allan Drazen, Mitsuhiro Fukao, Pierre-Olivier Gourinchas, Takeo Hoshi, Taka Ito, Chad Jones, Elias Papaioannou, Etsuro Shioji, Mark Spiegel, Shang-Jin Wei, and workshop participants at TRIO and the Universities of Pennsylvania and Washington. The data set, key output, and a current version of the paper are available at my website. The views expressed herein are those of the author(s) and do not necessarily reflect the views of the National Bureau of Economic Research.

(C2006 by Andrew K. Rose. All rights reserved. Short sections of text, not to exceed two paragraphs, may be quoted without explicit permission provided that full credit, including $\odot$ notice, is given to the source. 
Size Really Doesn't Matter: In Search of a National Scale Effect

Andrew K. Rose

NBER Working Paper No. 12191

April 2006

JEL No. O57

\begin{abstract}
I search for a "scale" effect in countries. I use a panel data set that includes 200 countries over forty years and link the population of a country to a host of economic and social phenomena. Using both graphical and statistical techniques, I search for an impact of size on the level of income, inflation, material well-being, health, education, the quality of a country's institutions, heterogeneity, and a number of different international indices and rankings. I have little success; small countries are more open to international trade than large countries, but are not systematically different otherwise.
\end{abstract}

Andrew K. Rose

Haas School of Business Administration

University of California

Berkeley, CA 94720-1900

and NBER

arose@haas.berkeley.edu 


\section{Motivation and Summary}

Countries differ a lot in size. As of July 2005, there were over 64,000 Chinese for each

of the 20,303 residents of Palau. ${ }^{1}$ There are now eleven countries with populations in excess of 100 million, and eleven with populations less than 100 thousand. This is a striking fact; there appears to be no optimal country size, and no noticeable convergence towards one. ${ }^{2}$

Nations do not come in standard sizes. This may seem natural, even obvious; after all, there is enormous variation in the size of firms and cities (as well as mammals and galaxies, among other things). ${ }^{3}$ This variation leads to an interesting question that is the subject of this short exploratory paper: does the size of a country matter? I take a broad-brush empirical approach and ask whether larger countries perform systematically different than larger countries in a number of different economic and social dimensions. They do not.

\section{Why Might Size Matter?}

There has been little quantitative work that on the linkages between country size and country performance. Accordingly, as an exploratory analysis this paper takes the "Estimate, don't test" message seriously. But while there is little empirical work, numerous theorists have discussed the effects of national size, especially in recent economics and not-so-recent political philosophy. Much recent economics has "scale effects" so that larger countries should be more successful countries. At the other extreme, a number of celebrated political philosophers argue that smaller countries make better states. There is also a strand of reasoning that articulates a tradeoff between the benefits and costs of size. I now review these briefly; my objective is simply to point out that size matters in a number of different literatures. 
Bigger is Better. Size has an effect on output in a number of different recent literatures of interest in economics. Increasing returns remain an intrinsic part of the "new wave" trade theory that began in the 1980s, and lead to offshoots in economic geography and urban economics. Agglomeration effects are also an important element of endogenous macroeconomic growth. Finally, they are part of the political economy literature that focuses on the provision of public goods. There is also a long tradition in political philosophy arguing that size is positively disadvantageous.

Helpman and Krugman (1985) analyze the impact of increasing returns on trade, and discuss economies of scale both internal and external to the firm. The former can be due to plant-runs or dynamic scale economies; while the latter can be due to an effect of scale on the variety of intermediate inputs, effects on market structure, or information spillovers. When there are increasing returns to scale and transportation costs, countries also exert a "home market effect" (Krugman, 1980). Agglomeration effects are also used in modeling urban dynamics as part of the new economic geography (e.g., Fujita, Krugman, and Venables 1999 and RossiHansberg and Wright, 2004). Indeed, the importance of numerous "border" effects is consistent with the fact that a number of economic relations are more efficient within a single country than in separate countries (Hess and van Wincoop, 2000; Drazen, 2000).

The literature on scale effects in macroeconomics stretches back a long way to Adam Smith's idea that the specialization of labor is limited by the extent of the market. Robinson (1960) lists a number of reasons why there might be scale effects across countries, including: enhanced intra-national integration (of capital, goods, and especially labor and services markets); higher productivity due to enhanced specialization or longer production runs; a scale effect on competition; and greater ability to respond flexibly to technological progress. 
Much recent work in growth theory has formalized such scale effects. Many models rely on learning by doing and/or knowledge spillovers, and result in the conclusion that larger countries should grow faster: e.g., Barro and Sala-i-Martin (1995). Indeed, scale effects are generic to endogenous growth models (Aghion and Howitt, 1998 p 28). Jones (1999, p 143) discusses three classes of endogenous growth models and shows that they all have a scale effect: "the size of the economy affects either the long-run growth rate or the long-run level of per capita income" since larger countries can support more research which delivers a higher level or growth rate of productivity. A recent survey provided by Ventura (2005) refers (p 92) to "the standard idea that economic growth in the world economy is determined by a tension between diminishing returns and market size effects to capital accumulation.”

The most authoritative work of relevance in public economics is the recent book by Alesina and Spolaore (2003), hereafter AS. They list (pp 3-4) five benefits of large population size: 1) lower per-capita costs of public goods (monetary and financial institutions, judicial system, communication infrastructure, police and crime prevention, public health, etc) and more efficient tax systems; 2) cheaper per-capita defense and military costs; 3 ) greater productivity due to specialization (though access to international markets may reduce this effect); 4) greater ability to provide regional insurance; and 5) greater ability to redistribute income within the country.

Tradeoffs Exist. In all this work, larger countries are predicted to be richer or more efficient. There is little analysis of the costs of size. AS discuss two costs of larger country size. A minor consideration is the potential for administrative and/or congestion costs. The only real issue of import is that larger countries have more diverse preferences, cultures, and languages. The AS hypothesis (p 6) is that "on balance, heterogeneity of preferences tends to bring about 
political and economic costs that are traded off against the benefits of size." ${ }^{.4}$ This reasoning is not new. In chapter XVII of the Leviathan Hobbes argued that small populations were insufficient to deter invasion and provide security, while excessively large countries would be incapable of the common defense because of lack of a common purpose and internal distractions. Olson (1982) argues that small homogenous societies are less burdened by the logic of collective action and have more capacity to create prosperity; see also Robinson (1960) and Wei (1991). ${ }^{5}$

Small is Beautiful. In arguing that size has its costs, AS join a long tradition of political philosophers, many of whom believe that small is beautiful. Plato quantified the optimal size of a city-state at 5,040 households. ${ }^{6}$ Similarly in Politics Aristotle argued that a country should be small enough for the citizens to know (and hear!) each other; the entire territory should be small enough to be surveyed from a hill. More recently, Rousseau stated:

"Large populations, vast territories! There you have the first and foremost reason for the misfortunes of mankind, above all the countless calamities that weaken and destroy polite peoples. Almost all small states, republics and monarchies alike, prosper, simply because they are small, because all their citizens know each other and keep an eye on each other, and because their rulers can see for themselves the harm that is being done and the good that is theirs to do and can look on as their orders are being executed. Not so the large nations: they stagger under the weight of their own numbers, and their peoples lead a miserable existence -- either, like yourselves, in conditions of anarchy, or under petty tyrants that the requirements of hierarchy oblige their kings to set over them."

This line of reasoning stretches all the way to at least Myrdal (1968).

Montesquieu famously believed that republican countries were necessarily small in both territory and population. His logic was that large countries were necessarily diverse and thus required strong governments, resulting in monarchies or even despots (for very large countries). Small countries without excessive wealth were the most democratic. He famously wrote: 
"In a large republic, the common good is sacrificed to a thousand considerations; it is subordinated to various exceptions; it depends on accidents. In a small republic, the public good is more strongly felt, better known, and closer to each citizen; abuses are less extensive, and consequently less protected." ${ }^{8}$

Interestingly, Montesquieu's logic was inverted by David Hume (1752), who argued in "Idea of a Perfect Commonwealth" that

" in a large government, which is modeled with masterly skill, there is compass and room enough to refine the democracy, from the lower people, who may be admitted into the first elections or first concoction of the commonwealth, to the higher magistrate, who direct all the movements. At the same time, the parts are so distant and remote, that it is very difficult, either by intrigue, prejudice, or passion, to hurry them into any measure against the public interest."

Madison famously used this logic to argue that large countries were less likely to be affected by factions in The Federalist Papers $10 .^{9}$

\section{Previous Empirics}

To my knowledge, there has been only almost no work on a national scale effect on the level of economic well-being (Drazen, 2000 argues that the reverse is also true). A number of different studies in Robinson (1960) tested for economies of scale and found them to be mostly unimportant. They also considered the impact of country size on national patterns of specialization, diversification, and competition, usually with a similar lack of success.

By way of contrast, there has been much work done which searches for a scale effect in economic growth. Barro and Sala-i-Martin (1995) are typical of the literature and provide limited evidence of a scale effect on growth. Alcalá and Ciccone (2003) finds an effect of market size on growth, although Sala-i-Martin (1997) does not using a general structure econometric search methodology. Alesina, Spolaore, and Wacziarg $(2000,2004)$ focus on 
whether the effect (if any) of size on growth is mediated through openness; they find moderately supportive results using a panel of data and IV techniques. ${ }^{10}$ But most of the focus in AS is in the causes and determination of country size rather than its effects.

The theoretical work in the literature implies that one might expect to find an effect of size on: output; inflation; communications infrastructure; crime; health; output and productivity; inequality; and heterogeneity. Rather than return to investigating growth, I now attempt to extend the search for scale effects and investigate whether a country's population has a substantial effect on the level of economic activity.

\section{Empirics}

My strategy in this paper is to take a broad-brush approach to the effect of scale on economic and social phenomena. I look at a large number of variables that are potentially affected by a country's population size, choosing them either on the basis of intrinsic interest or because they are suggested by the literature. I search for signs of a scale effect using both graphs and more conventional statistical techniques.

The heart of my data set consists of populations sampled at decadal intervals, starting in 1960 and proceeding through 2000. My default source for population data (and indeed for many series) is The World Development Indicators, produced by the World Bank. A few missing population observations are filled in from old versions of the CIA's World Factbook and the UN's Statistical Yearbook, so that I have observations on 208 "countries" for each of 5 different

years. A list of the countries included is tabulated in Appendix Table A1; the sources for my key variables are tabulated in Table A2, and some descriptive statistics are provided in Table A3. 
The only "country" I exclude of any size is Taiwan, province of China (for data availability reasons). Which brings me to the word "country."

There is no universal definition of a "country." Economists often ignore places such as Niue, a small island in the South Pacific that has been self-governing in free association with New Zealand since 1974 and had an estimated 2005 population of 2,166. Is Niue really a “country?" As of July 2005, Tuvalu had a population estimated to be 11,636; Nauru had 13,048 people, and San Marino 28,880. ${ }^{11}$ None of these countries has military forces, a currency, or an embassy in the United States, but all were members of the United Nations. Are any or all of these countries? If none, what about Tonga home to just over 110,000 people? Luxembourg, with less than half a million? Slovenia with two million? If one has to draw the line, where should it be and why?

My default is to consider as "countries" all entities referred to as such by the World Development Indicators (WDI) in 2005. This is worthy of some discussion. First, this includes a number of entities sometimes not considered to be "countries" such as the Cayman Islands (a British crown colony), Hong Kong (a special administrative region of China), Mayotte (a territorial collectivity of France), Puerto Rico (a commonwealth associated with the United States), and the West Bank and Gaza strip (not internationally recognized as a de jure part of any country). Further, countries that existed in 2005 did not necessarily exist in 1960, and vice versa. For instance, the USSR and Yugoslavia have split into multiple countries; East Germany and the separate Yemens no longer exist. I follow my reasoning not simply because of ease. It seems natural, since it adheres to both the Ricardian notion that factors such as labor are more mobile within a country than between countries, and to the existence of a central government with a monopoly on legal coercion. ${ }^{12}$ Most entities that are only questionably "countries" a) have small 
populations, and b) are often missing data on variables of interest. Thus my results do not typically depend on the exact definition of "country."

Figure A1 in the appendix presents histograms of the population of all independent sovereign nations at decadal intervals between 1950 and 2000. It shows that there is little change in either the mean or median log population of a country since WWII, though dispersion in country size has been slowly rising.

\section{A Visual Approach}

Are there benefits or costs to a country being larger? I begin with a visual survey of the relationship between the size and attributes of countries. ${ }^{13}$ Size is equated with population, as is reasonably standard. ${ }^{14}$ I present a series of graphs where different variables are plotted (on the ordinate or y-axis) against the natural logarithm of population (on the abscissa or x-axis); each country is marked by a dot. This graphical analysis is exclusively cross-sectional in nature. I try to match dates of the variable of interest to that of the population, and use recent data where possible. $^{15}$

Figure 1 provides scatter-plots of (the natural logarithm of) real GDP per capita against (log) population at decadal intervals from 1960 through 2000; both series are taken from the WDI. Data on income adjusted for deviations from purchasing power party (PPP) are available from 1980 on, while dollar values are available from 1960. Each of the points marked represents a country. A linear regression line is also provided; the robust t-statistic for the slope coefficient is recorded beneath each scatter-plot. Significant scale economies would lead one to expect real output per person to increase with country size. However, all eight graphs exhibit a weakly 
negative relationship between real income per capita and country size. There is certainly no visual evidence that larger countries are richer.

Figure 2 examines the relationship between country size and a number of other measures of economic well-being using the same graphical technique. One popular composite measure of well-being is the "Human Development Index" which I take from the UNDP's Human Development Report. ${ }^{16}$ High human development is insignificantly but negatively associated with country size. More traditional measures of economic well-being are also presented and deliver the same message. Since a few countries had relatively high inflation in 2000, I scatter CPI inflation against population size for both the whole sample and excluding the (eleven) countries with annual inflation exceeding $20 \% .{ }^{17}$ Both scatters show an insignificant positive relation between country size and inflation, despite the view of e.g., Alesina and Spolaore that financial institutions might be expected to be superior and deliver lower inflation in larger countries. It is reassuring to note that openness (trade as a percentage of GDP) is strongly negatively associated with country size, as is widely known and expected (e.g., Alesina, Spolaore and Wacziarg, 2004, Dahl and Tufte, 1973, Robinson, 1960). ${ }^{18}$ Military spending (again, as a percentage of GDP) is however not significantly tied to country size. It is also interesting that per capita ownership of automobiles, televisions, telephones, and personal computers all seem to decline (usually not significantly so) with country size.

Health and education are critical phenomena, both intrinsically and as measures or manifestations of economic development. Further, key parts of education and healthcare are often largely provided by the state; economies of scale in providing these public goods might be expected to lead to strong linkages between country size and policy outcomes. But there is in fact little evidence that larger states systematically provide better health and education from 
Figure 3. Outcome measures such as life expectancy at birth (in 2000) declined (slightly) with country size, while the infant mortality rate rose (significantly). Input measures such as immunization rates, access to clean water and sanitation were all higher in smaller countries. The rates of literacy, primary school completion, and (both net and gross) secondary school enrollment all fell with country size. ${ }^{19}$

Figure 4 presents evidence on twelve different measures of institutional quality, linking each to country size in 2000. Larger countries tend to be more democratic (though not significantly so), when democracy is quantified with the standard Polity $I V$ composite measure. ${ }^{20}$ But political rights, civil rights, and freedom (as measured by Freedom House) are significantly lower in larger countries. ${ }^{21}$ The same is true of two of the KKZ governance indicators: Voice \& Accountability and Political Stability, while the perception of corruption is significantly higher in larger countries too. ${ }^{22}$ The other KKZ measures (Government Effectiveness, Regulatory Quality, the Rule of Law, Control of Corruption, and the Hall and Jones, 1999 measure of "Social Infrastructure") are also (insignificantly) lower in larger countries. This negative set of findings is interesting since it implies that there is little reason to believe that smaller countries respond endogenously to scale disadvantages by being more responsive to public demands.

Many composite measures have been developed of late to compare and rank countries in a number of ways; six popular ones are presented in Figure 5. They are: a) "Economic Freedom" as measured by the Heritage Foundation; b) "Country Credit Rating" provided by Institutional Investor magazine; c) the "Country Composite Risk Rating" developed by ICRG/Political Risk Services; d) the "Competitiveness Ranking" from the Swiss business school IMD (2000); e) the “Competitiveness Ranking” from the World Economic Forum (2000), also in Switzerland; and f) the "Economic Security Index" from the ILO. ${ }^{23}$ None of the correlations indicates that large 
countries compare well. Economic freedom, country ratings, country risk, competitiveness, and economic security all fall as country size rises.

The last three variables portrayed in Figure 5 are associated with financial depth. I examine: a) M3 (liquid liabilities), b) quasi-liquid liabilities (M2), and c) domestic credit provided by the banking sector, all measured as percentages of GDP. ${ }^{24}$ None of the three indicators is significantly correlated with country size; two of the three fall with size.

To summarize: an ocular examination of Figures 1-5 provides no evidence of any strong tie between the size of a country and standard measures of economic comfort or well-being. Larger countries just do not seem to be more developed than small countries in any systematic way.

Perhaps economic well-being and national institutions do not improve with country size because larger nations are systematically more diverse? This hypothesis, suggested by a number of scholars, is investigated in Figure 6, which compares country size with nine different measures of national heterogeneity. Each of the small graphs presents a scatter-plot of a different measure of national heterogeneity against the natural logarithm of population.

There is little evidence that large countries are consistently and significantly more heterogeneous than smaller countries. The graphs are arranged so that heterogeneity rises along the ordinate (y-axis). If larger countries are more heterogeneous, the data should exhibit a positive slope. Six of the nine slopes are indeed positive. However, only one is significantly different from zero at conventional significance levels, the measure of linguistic diversity provided by Ethnologue. Still, the other measure of linguistic fractionalization (provided by Alesina et al, 2003) is insignificantly linked to size (the two measures of linguistic heterogeneity have a correlation of .81). Further, ethnic polarization is significantly negatively associated with 
country size (the Gini coefficient and one of the two measures of religious fractionalization are negatively but insignificantly linked to size). ${ }^{25}$

To sum up, there seems to be no strong visual relationship between a country's population and a host of social phenomena of relevance. Larger countries do no seem to be much richer, healthier, better educated, more diverse, or better off than smaller countries. There is also little evidence from any of the graphical evidence above that one or two outlier countries dominate the data. The first impression one gets is that size simply does not matter.

\section{A Statistical Approach}

The graphical analysis presented above is suggestive but not definitive. For one thing, the analysis is bivariate, and does not control for other phenomena that might be relevant. Accordingly, I now verify my visual findings with more rigorous statistical analysis. I use regression analysis to search for a relationship between size and the variables of interest graphed above (as always, defining size to be the natural logarithm of population).

I estimate regressions in a number of different ways. I use three estimators: OLS; fixed effects (when the variables are available for a number of different years); and instrumental variables. Even though there may be little reason to believe that a country's size is endogenous in any important sense (Drazen, 2000), I use the log of total country area as an instrumental variable for the log of population. ${ }^{26}$ An intercept is included in all regressions; when the variables are available for a number of different years, I also include time-specific fixed effects.

I also estimate both simple bivariate models and models augmented with a number of controls suggested by the literature. I use three different sets of control variables. I begin with a set of twenty: a) the urbanization rate, b) population density, c) the log of absolute latitude 
(kilometers from equator), d) binary dummy variable for landlocked country, e) island-nation dummy, f) High Income country dummy, g) regional dummies for developing countries from 1) Latin America, 2) Sub-Saharan Africa, 3) East Asia, 4) South Asia, 5) Europe-Central Asia, 6) and Middle East-North Africa, and h) language dummies for countries that speak 1) English, 2) French, 3) German, 4) Dutch, 5) Portuguese, 6) Spanish, 7) Arabic, and 8) Chinese. My second set of control variables augments the first set with an additional five: a) dummy for countries created post-WW2, b) dummy for countries created after 1800 but before 1945, c) dependency dummy, d) OPEC dummy, and e) COMECON dummy. My last set of controls adds two more variables to the second set: a) $\log$ real GDP per capita in $\$$, and b) the proportion of land within $100 \mathrm{~km}$ of ice-free coastline or navigable river. ${ }^{27}$

To summarize, I tabulate estimates of the coefficient of interest $\beta$ which I estimate from:

$$
\mathrm{y}_{\mathrm{it}}=\beta \ln \left(\mathrm{Pop}_{\mathrm{it}}\right)+\alpha+\left\{\gamma_{\mathrm{t}} \mathrm{T}_{\mathrm{t}}\right\}+\Sigma_{\mathrm{j}} \delta_{\mathrm{j}} \mathrm{X}_{\mathrm{ijt}}+\left\{\zeta_{\mathrm{i}} \mathrm{I}_{\mathrm{i}}\right\}+\varepsilon_{\mathrm{it}}
$$

where:

$0 \mathrm{y}$ is a dependent variable of interest for country $\mathrm{i}$ at year $\mathrm{t}$,

o Pop denotes population,

o $\left\{\mathrm{T}_{\mathrm{t}}\right\}$ and $\left\{\mathrm{I}_{\mathrm{i}}\right\}$ denote mutually exclusive and jointly exhaustive sets of time- and country-specific fixed effects,

o $\left\{\mathrm{X}_{\mathrm{j}}\right\}$ denotes a set of control variables.

$0 \quad \varepsilon$ is a well-behaved residual, and

o $\alpha,\{\gamma\},\{\delta\},\{\zeta\}$ are nuisance coefficients. 
Table 1 records the slope coefficient on country size, along with a robust standard error. It is split into six panels, corresponding to the six different sets of graphics; each row corresponds to a different dependent variable. The coefficients on the nuisance parameters (for the control variables) are suppressed since they are not of intrinsic interest. The seven columns correspond to: a) bivariate OLS with $\{\delta\}=\{\zeta\}=0$; b) OLS with $\{\zeta\}=0$, controls set \#1; c) OLS with $\{\zeta\}=0$, controls set $\# 2$; d) OLS with $\{\zeta\}=0$, controls set $\# 3$; e) fixed effects with $\{\delta\}=0$; f) IV with $\{\delta\}=\{\zeta\}=0$; and g) IV with $\{\zeta\}=0$, controls set $\# 3$.

Panel A shows that the real income per person is almost always negatively correlated with size. When the data are pooled across years, the relationship is significant at standard confidence levels when controls are included. The same is true of most cross-sections, and all the bivariate IV results; it seems reasonable to conclude that larger countries are not systematically richer. If anything, the opposite is a better description of the data. Table A4 provides extensive sensitivity analysis that shows that confirms this conclusion.

Panel B focuses on the effect of size on a set of economic measures. The results indicate that there is only one reliable relationship: small countries are systematically and substantially more open than larger countries. The effect is economically and statistically significant: a country that is $1 \%$ larger in population does about $14 \%$ less trade (as a percentage of GDP). This not only reproduces conventional wisdom but shows that the techniques I employ can reveal significant relationships in the data.

The linkages between country size and its health and education are examined in Panel C. Almost all the coefficients estimated are insignificant, and a number show that larger countries are associated with worse outcomes. Of the eight OLS estimates that are significantly differently different from zero at the .05 level, four show that size helps. All nine bivariate IV estimates are 
significant, and all indicate that larger countries perform worse (though these are insignificant when controls are added). The results are also poor in Panel D, which searches for an effect of size on institutions. Again, most of the coefficients are indistinguishable from zero. Of the twenty-nine significant coefficients, only six indicate that size is associated with better institutions. The estimates of Panel $\mathrm{E}$ link size to six international rankings and three measures of financial depth. Only domestic bank credit (measured as a percentage of GDP) rises significantly with GDP, and even then only when OLS is used but fixed country effects are not included (the within estimator is significantly negative).

Panel F confirms that my nine measures of national heterogeneity are not closely tied to country size with OLS techniques. Of the thirty-six coefficients tabulated, five are significantly different from zero at the .05 level or better. Of these, three link size positively to heterogeneity while ethnic polarization is significantly lower for larger countries in two of the four regressions. On the other hand, five of the nine bivariate IV estimates indicate that larger countries are significantly more heterogeneous than smaller countries. Even this moderate result is fragile: only one of the nine coefficients (that for geographic dispersion) is significantly positive when controls are added.

To summarize: the statistical analysis broadly confirms the impression left by the graphs. There is little evidence that countries with more people perform measurably better. Indeed a good broad-brush characterization is that a country's population has no significant consistent impact on its well-being. The one strong and well-known exception is that smaller countries are consistently and significantly more open to international trade than larger countries. ${ }^{28}$ 


\section{Remaining Issues}

It would be natural and interesting to compare crime rates across countries. The key issue here is the fact that different jurisdictions collect crime data in incompatible ways; in 2000, the UN data set indicates that the country with the lowest crime rate was Pakistan with a rate of 2.23/100,000 inhabitants (the second-highest crime rate was Sweden in 1990 with 14,240). ${ }^{29} \mathrm{~A}$ simple regression of the crime rate against the log of population delivers a negative effect of country size on the crime rate if one controls for year effects, but a positive effect if one controls for country effects. It would also be interesting to extend the analysis to cover conflicts, civil and external. ${ }^{30}$ Finally, the post-war patterns may not be representative of earlier periods of time, especially given the large waves of migration that have occurred historically. Indeed, if an accurate data set could be constructed, emigration and immigration would be useful to analyze since they are prima facie indicators of a country's well-being.

\section{Summary and Conclusion}

This paper is motivated by the fact that countries have vastly different sizes. To my knowledge, there is no theoretical model that explains the wide variation in size across countries. Should we worry? My initial answer is negative. In this empirical paper, I have searched for but not found evidence that country size (measured as population) matters for economic outcomes. More precisely, I have not been able to find a consistent strong country scale effect on any phenomena other than openness. Country size simply seems not to matter.

This seems unsurprising. If larger countries offered a systematically higher quality of life, this would be part of common culture and received street wisdom. My finding is also 
consistent with received wisdom; for instance Dahl and Tufte $(1973$, p19) state “... we also find that levels of socioeconomic development are independent of total population ..."

While this work is an exploratory exercise, it does have ramifications for existing academic research. Many economic models - in economic growth, international trade, urban economics, and public finance - imply that the size of larger countries is economically advantageous in should deliver higher output, cheaper public goods, and so forth. A number of political philosophers argue that larger countries should have inferior institutions. Given the theoretical importance of size in many economic and political models, it may also be interesting to ask why size seems not to matter. Scale effects may occur only at the sub-national level. I find no evidence that small countries endogenously overcome their disadvantages by becoming more effective at providing public or private goods, others may have more success in finding offsetting effects. There may also be more subtle ways to find national scale effects, e.g., by employing different controls or more structural techniques. Such issues may warrant future research.

Agents with large endowments tend to be proud of them, often considering them to be so intrinsically valuable as to compensate for a variety of other defects. Are they? In this paper I have asked whether countries endowed with large populations have measurably higher economic welfare. The answer is negative; the size - population - of a country seems to have little relationship to most anything of economic interest. This seems intuitive, is consistent with conventional wisdom and allows one to understand that countries vary enormously in size. A country's size just doesn't seem to matter for its economic institutions and performance. 


\section{References}

Aghion, Philippe and Peter Howitt (1998) Endogenous Growth Theory (MIT Press: Cambridge).

Alcalá, Francisco and Antonio Ciccone (2003) "Trade, Extent of the Market, and Economic Growth 1960-1996" unpublished.

Alesina, Alberto, Arnaud Devleeschauwer, William Easterly, Sergio Kurlat and Romain Wacziarg (2003) “Fractionalization” Journal of Economic Growth 8, 155-194.

Alesina, Alberto and Enrico Spolaore (2003) The Size of Nations (MIT Press: Cambridge).

Alesina, Alberto, Enrico Spolaore, and Romain Wacziarg (2004) "Economic Integration and Political Disintegration” American Economic Review 90-5, 1276-1296.

Alesina, Alberto, Enrico Spolaore, and Romain Wacziarg (2004) "Trade, Growth and the Size of Countries" forthcoming in Aghion and Durlauf (eds.), Handbook of Economic Growth (North Holland: Amsterdam).

Barro, Robert J. and Xavier Sala-i-Martin (1995) Economic Growth (McGraw-Hill: New York).

Collier, Paul and Anke Hoeffler (2004) "Greed and Grievance in Civil War" Oxford Economic Papers 56(4), 563-595.

Dahl, R.A. and E.R. Tufte (1973) Size and Democracy (Stanford University Press: Stanford).

Drazen, Allan (2000) Political Economy in Macroeconomics (Princeton University Press: Princeton).

Fujita, Masahisa, Paul Krugman and Anthony Venables (1999) The Spatial Economy (MIT Press: Cambridge).

Gallup, John Luke, Jeffrey D. Sachs and Andrew D. Mellinger (1998) "Geography and Economic Development" NBER Working Paper No. 6849.

Hall, Robert E. and Charles I. Jones (1999) "Why Do Some Countries Produce So Much More Output per Worker than Others?” Quarterly Journal of Economics 114-1, 83-116.

Helpman, Elhanan and Paul R. Krugman (1985) Market Structure and Foreign Trade (MIT Press: Cambridge).

Hess, Gregory D. and Eric van Wincoop (2000) Intranational Macroeconomics (Cambridge University Press: Cambridge),

International Institute for Management Development (2000) The World Competitiveness Yearbook 2000. 
International Labour Organization (2004) Economic Security for a Better World (ILO: Geneva).

Jones, Charles I. (1999) "Growth: With or Without Scale Effects?" American Economic Review 89-2, 139-144.

Krugman, Paul R. (1980) "Scale Economies, Product Differentiation and the Pattern of Trade" American Economic Review 70-5, 950-959.

Myrdal, Gunnar (1968) Asian Drama: An Inquiry into the Poverty of Nations (Pantheon Press: New York).

Olson, Mancur (1982) The Rise and Decline of Nations (Yale University Press: New Haven).

Robinson, E.A.G. (1960) Economic Consequences of the Size of Nations (St. Martin's Press: New York).

Rossi-Hansberg, Esteban and Mark Wright (2004) "Urban Structure and Growth” unpublished.

Sala-i-Martin Xavier X. (1997) “I Just Ran Four Million Regressions” NBER Working Paper No 6252.

Ventura, Jaume (2005) “A Global View of Economic Growth” NBER Working Paper 11,296.

Wei, Shang-Jin (1991) “To Divide or to Unite? A Theory of Secession” unpublished.

World Economic Forum (2000) The Global Competitiveness Report 2000 (Oxford University Press: Oxford). 
Table 1: Regression Results

Panel A: Income

\begin{tabular}{|r|c|c|c|c|c|c|c|}
\hline $\begin{array}{r}\text { Dependent } \\
\text { Variable }\end{array}$ & Bivariate & $\begin{array}{c}\text { Controls, } \\
\text { Set 1 }\end{array}$ & $\begin{array}{c}\text { Controls, } \\
\text { Set 2 }\end{array}$ & $\begin{array}{c}\text { Controls, } \\
\text { Set 3 }\end{array}$ & $\begin{array}{c}\text { Fixed } \\
\text { Effects }\end{array}$ & IV & $\begin{array}{c}\text { IV with } \\
\text { Controls }\end{array}$ \\
\hline Log \$ Real GDP & -.08 & $-.08^{* *}$ & $-.12^{* *}$ & $-.12^{* *}$ & $-.62^{* *}$ & $-.21^{* *}$ & -.06 \\
Per capita Pooled & $(.06)$ & $(.03)$ & $(.03)$ & $(.04)$ & $(.16)$ & $(.07)$ & $(.05)$ \\
\hline Log \$ Real GDP & -.07 & -.07 & -.10 & -.07 & & $-.26^{*}$ & .05 \\
per capita 1960 & $(.09)$ & $(.05)$ & $(.05)$ & $(.06)$ & & $(.11)$ & $(.08)$ \\
\hline Log \$ Real GDP & -.07 & -.08 & $-.12^{*}$ & $-.13^{*}$ & & $-.21^{*}$ & -.09 \\
per capita 1970 & $(.08)$ & $(.04)$ & $(.05)$ & $(.06)$ & & $(.10)$ & $(.08)$ \\
\hline Log \$ Real GDP & -.07 & $-.08^{*}$ & $-.11^{* *}$ & $-.15^{* *}$ & & $-.17^{*}$ & $-.14^{*}$ \\
per capita 1980 & $(.06)$ & $(.04)$ & $(.04)$ & $(.05)$ & & $(.08)$ & $(.07)$ \\
\hline Log \$ Real GDP & -.09 & $-.08^{*}$ & $-.11^{* *}$ & $-.09^{*}$ & & $-.20^{* *}$ & -.07 \\
per capita 1990 & $(.05)$ & $(.03)$ & $(.03)$ & $(.04)$ & & $(.07)$ & $(.06)$ \\
\hline Log \$ Real GDP & -.10 & $-.09^{*}$ & $-.13^{* *}$ & $-.10^{*}$ & & $-.22^{* *}$ & -.05 \\
per capita 2000 & $(.05)$ & $(.04)$ & $(.04)$ & $(.05)$ & & $(.07)$ & $(.07)$ \\
\hline Log PPP Real GDP & -.07 & $-.06^{*}$ & $-.08^{* *}$ & $-.08^{*}$ & $-.54^{* *}$ & $-.16^{* *}$ & -.04 \\
per capita pooled & $(.04)$ & $(.03)$ & $(.03)$ & $(.03)$ & $(.20)$ & $(.05)$ & $(.05)$ \\
\hline Log PPP Real GDP & -.05 & -.05 & -.06 & $-.10^{*}$ & & $-.12^{*}$ & -.11 \\
per capita 1980 & $(.05)$ & $(.03)$ & $(.03)$ & $(.04)$ & & $(.06)$ & $(.07)$ \\
\hline Log PPP Real GDP & -.07 & $-.05^{*}$ & $-.07^{*}$ & -.06 & & $-.17^{* *}$ & -.03 \\
per capita 1990 & $(.04)$ & $(.02)$ & $(.03)$ & $(.03)$ & & $(.05)$ & $(.05)$ \\
\hline Log PPP Real GDP & $-.09^{*}$ & $-.08^{*}$ & $-.11^{* *}$ & -.07 & & $-.19^{* *}$ & -.02 \\
per capita 2000 & $(.04)$ & $(.04)$ & $(.04)$ & $(.05)$ & & $(.06)$ & $(.06)$ \\
\hline
\end{tabular}

Panel B: Economic Indicators

\begin{tabular}{|r|c|c|c|c|c|c|c|}
\hline $\begin{array}{r}\text { Dependent } \\
\text { Variable }\end{array}$ & Bivariate & $\begin{array}{c}\text { Controls, } \\
\text { Set 1 }\end{array}$ & $\begin{array}{c}\text { Controls, } \\
\text { Set 2 }\end{array}$ & $\begin{array}{c}\text { Controls, } \\
\text { Set 3 }\end{array}$ & $\begin{array}{c}\text { Fixed } \\
\text { Effects }\end{array}$ & IV & $\begin{array}{c}\text { IV with } \\
\text { Controls }\end{array}$ \\
\hline Index & $(.01)$ & -.003 & -.006 & .003 & .03 & $-.03^{*}$ & -.00 \\
& $(.004)$ & $(.004)$ & $(.003)$ & $(.03)$ & $(.01)$ & $(.01)$ \\
\hline CPuman Development & 13.2 & 11.9 & 14.7 & 3.9 & 54. & 23.2 & -1.1 \\
& $(7.8)$ & $(10.8)$ & $(12.1)$ & $(22.4)$ & $(54)$ & $(12.0)$ & $(24.1)$ \\
\hline Trade Openness & $-13.3^{* *}$ & $-14.4^{* *}$ & $-13.5^{* *}$ & $-13.2^{* *}$ & -15.7 & $-17.6^{* *}$ & $-15.3^{* *}$ \\
(\% GDP) & $(1.1)$ & $(1.5)$ & $(1.5)$ & $(1.7)$ & $(9.4)$ & $(2.3)$ & $(2.7)$ \\
\hline Military Spending & -.2 & -.3 & -.6 & -.4 & & -.2 & -.3 \\
(\% GDP) & $(.2)$ & $(.3)$ & $(.3)$ & $(.2)$ & & $(.4)$ & $(.3)$ \\
\hline Cars per capita & -3.7 & -1.2 & -2.5 & 2.1 & $-242 . *^{* *}$ & -7.9 & 14.5 \\
& $(9.2)$ & $(5.5)$ & $(5.2)$ & $(5.9)$ & $(55)$. & $(12.3)$ & $(9.7)$ \\
\hline TVs per capita & -9.3 & 8.0 & 5.2 & $18.2^{* *}$ & $-190 * *$ & $-24.5^{* *}$ & $28.4^{* *}$ \\
& $(7.2)$ & $(4.9)$ & $(4.4)$ & $(5.0)$ & $(67)$. & $(9.5)$ & $(7.8)$ \\
\hline Telephones per capita & -.9 & .5 & -3.9 & -3.9 & & -14.1 & -1.7 \\
& $(6.1)$ & $(3.6)$ & $(3.4)$ & $(3.6)$ & & $(8.2)$ & $(5.9)$ \\
\hline PCs per capita & -6.6 & -1.2 & -4.4 & 3.4 & -442 & -13.8 & 10.1 \\
& $(5.9)$ & $(5.4)$ & $(5.5)$ & $(4.3)$ & $(312)$ & $(7.9)$ & $(6.5)$ \\
\hline
\end{tabular}


Panel C: Health and Education

\begin{tabular}{|r|c|c|c|c|c|c|c|}
\hline $\begin{array}{r}\text { Dependent } \\
\text { Variable }\end{array}$ & Bivariate & $\begin{array}{c}\text { Controls, } \\
\text { Set 1 }\end{array}$ & $\begin{array}{c}\text { Controls, } \\
\text { Set 2 }\end{array}$ & $\begin{array}{c}\text { Controls, } \\
\text { Set 3 }\end{array}$ & $\begin{array}{c}\text { Fixed } \\
\text { Effects }\end{array}$ & IV & $\begin{array}{c}\text { IV with } \\
\text { Controls }\end{array}$ \\
\hline $\begin{array}{r}\text { Life Expectancy } \\
\text { at Birth }\end{array}$ & .1 & .16 & -.1 & .2 & 2.9 & $-1.7^{* *}$ & -.4 \\
Rate & $(1.5)$ & $(.22)$ & $(.2)$ & $(.3)$ & $(1.7)$ & $(.6)$ & $(.5)$ \\
\hline Infant Mortality & 1.1 & -1.3 & -.9 & $-3.0^{*}$ & $-33.8^{* *}$ & $7.8^{* *}$ & .0 \\
Rate & $(.5)$ & $(.6)$ & $(1.0)$ & $(1.2)$ & $(5.2)$ & $(2.1)$ & $(2.3)$ \\
\hline DPT Immunization & $-1.5^{* *}$ & $-1.2^{*}$ & $-1.6^{* *}$ & -.0 & 24.3 & $-3.1^{* *}$ & -2.4 \\
\hline Improved Water & -1.2 & -.3 & -.2 & 2.9 & $(13.3)$ & $(.7)$ & $(1.5)$ \\
\hline \% pop) & $(.8)$ & $(1.0)$ & $(1.0)$ & $(1.3)$ & $(12.8)$ & $(1.1)$ & $(1.8)$ \\
\hline Sanitation Access & $-2.9^{*}$ & -.6 & -.8 & .1 & 16.0 & $-5.1^{* *}$ & -3.2 \\
(\% pop) & $(1.1)$ & $(1.2)$ & $(1.2)$ & $(1.4)$ & $(10.1)$ & $(1.5)$ & $(3.2)$ \\
\hline Literacy Rate & -1.8 & -.5 & -.1 & 1.5 & $20.8^{* *}$ & $-4.8^{* *}$ & .4 \\
$(>14)$ & $(1.0)$ & $(.9)$ & $(.8)$ & $(.9)$ & $(5.9)$ & $(1.4)$ & $(1.4)$ \\
\hline Primary School & -1.2 & .8 & .4 & $2.4^{*}$ & -17.3 & $-4.4^{* *}$ & 1.2 \\
Completion Rate & $(1.1)$ & $(1.0)$ & $(1.0)$ & $(1.1)$ & $(46.8)$ & $(1.4)$ & $(1.8)$ \\
\hline Gross Secondary School & -.4 & 1.0 & .8 & 1.1 & -.6 & $-2.7^{*}$ & 1.5 \\
Enrollment Rate & $(1.0)$ & $(.8)$ & $(.8)$ & $(.9)$ & $(17.7)$ & $(1.4)$ & $(1.3)$ \\
\hline Net Secondary School & -.8 & .2 & -.7 & .8 & 6.1 & $-3.6^{*}$ & .5 \\
Enrollment Rate & $(1.1)$ & $(1.1)$ & $(1.2)$ & $(1.1)$ & $(28.4)$ & $(1.4)$ & $(1.5)$ \\
\hline
\end{tabular}

Panel D: Institutions

\begin{tabular}{|r|c|c|c|c|c|c|c|}
\hline $\begin{array}{r}\text { Dependent } \\
\text { Variable }\end{array}$ & Bivariate & $\begin{array}{c}\text { Controls } \\
\text { Set 1 }\end{array}$ & $\begin{array}{c}\text { Controls } \\
\text { Set 2 }\end{array}$ & $\begin{array}{c}\text { Controls } \\
\text { Set 3 }\end{array}$ & $\begin{array}{c}\text { Fixed } \\
\text { Effects }\end{array}$ & IV & $\begin{array}{c}\text { IV with } \\
\text { Controls }\end{array}$ \\
\hline Polity & .5 & .3 & .4 & $.6^{*}$ & -2.4 & -.5 & $.8^{*}$ \\
(High=Democratic) & $(.4)$ & $(.3)$ & $(.3)$ & $(.3)$ & $(2.0)$ & $(.6)$ & $(.4)$ \\
\hline Political Rights & .13 & -.04 & -.03 & $-.16^{*}$ & $2.37^{* *}$ & $.26^{* *}$ & $-.30^{*}$ \\
(Low=Free) & $(.07)$ & $(.06)$ & $(.06)$ & $(.07)$ & $(.83)$ & $(.09)$ & $(.13)$ \\
\hline Civil Rights & $.18^{* *}$ & .02 & .02 & -.08 & 1.15 & $.29^{* *}$ & $-.21^{*}$ \\
(Low=Fre) & $(.06)$ & $(.05)$ & $(.05)$ & $(.06)$ & $(.63)$ & $(.08)$ & $(.10)$ \\
\hline Freedom & $.05^{*}$ & -.01 & -.01 & $-.07^{*}$ & $.91^{* *}$ & $.10^{* *}$ & $-.10^{*}$ \\
(Low=Fre) & $(.03)$ & $(.02)$ & $(.02)$ & $. .03)$ & $(.34)$ & $(.03)$ & $(.05)$ \\
\hline Voice\&Accountability & $-.14^{* *}$ & -.04 & -.05 & .01 & & $-.17^{* *}$ & .05 \\
(Higher=Better) & $(.03)$ & $(.03)$ & $(.03)$ & $(.04)$ & & $(.04)$ & $(.07)$ \\
\hline Political Stability & $-.17^{* *}$ & $-.14^{* *}$ & $-.15^{* *}$ & $-.10^{*}$ & & $-.28^{* *}$ & -.05 \\
(Higher=Better) & $(.05)$ & $(.04)$ & $(.04)$ & $(.04)$ & & $(.07)$ & $(.06)$ \\
\hline Gov't Effectiveness & -.01 & -.01 & -.02 & .00 & & -.08 & -.00 \\
(Higher=Better) & $(.03)$ & $(.03)$ & $(.03)$ & $(.04)$ & & $(.05)$ & $(.05)$ \\
\hline Regulatory Quality & -.01 & .02 & .01 & -.00 & & -.09 & -.12 \\
(Higher=Better) & $(.03)$ & $(.03)$ & $(.03)$ & $(.05)$ & & $(.05)$ & $(.07)$ \\
\hline Rule of Law & -.03 & -.02 & -.04 & -.03 & & $-.10^{*}$ & -.03 \\
(Higher=Better) & $(.03)$ & $(.02)$ & $(.02)$ & $(.03)$ & & $(.05)$ & $(.04)$ \\
\hline Control of Corruption & -.06 & -.06 & $-.08^{* *}$ & $-.07^{*}$ & & $-.11^{*}$ & -.04 \\
(Higher=Better) & $(.03)$ & $(.03)$ & $(.03)$ & $(.04)$ & & $(.05)$ & $(.05)$ \\
\hline Perceived Corruption & $-.66^{* *}$ & $-.39^{* *}$ & $-.45^{* *}$ & $-.39^{* *}$ & -1.07 & $-.76^{* *}$ & -.08 \\
(Higher=Better) & $(.11)$ & $(.08)$ & $(.08)$ & $(.08)$ & $(1.06)$ & $(.29)$ & $(.14)$ \\
\hline Social Infrastructure & -.01 & -.01 & -.01 & -.01 & & $-.05^{*}$ & -.03 \\
(Higher=Better) & $(.01)$ & $(.01$ & $(.01)$ & $(.01)$ & & $(.02)$ & $(.03)$ \\
\hline
\end{tabular}


Panel E: Ratings and Financial Depth

\begin{tabular}{|r|c|c|c|c|c|c|c|}
\hline $\begin{array}{r}\text { Dependent } \\
\text { Variable }\end{array}$ & Bivariate & $\begin{array}{c}\text { Controls, } \\
\text { Set 1 }\end{array}$ & $\begin{array}{c}\text { Controls, } \\
\text { Set 2 }\end{array}$ & $\begin{array}{c}\text { Controls, } \\
\text { Set 3 }\end{array}$ & $\begin{array}{c}\text { Fixed } \\
\text { Effects }\end{array}$ & IV & $\begin{array}{c}\text { IV with } \\
\text { Controls }\end{array}$ \\
\hline $\begin{array}{r}\text { Economic Freedom Index } \\
\text { (Higher=Better) }\end{array}$ & -.10 & -.05 & -.08 & -.05 & -.75 & $-.25^{*}$ & -.04 \\
& $(.06)$ & $(.04)$ & $(.04)$ & $(.04)$ & $(.39)$ & $(.12)$ & $(.07)$ \\
\hline $\begin{array}{r}\text { Institutional Invest. Credit } \\
\text { Rating (Higher=Better) }\end{array}$ & -.4 & 1.2 & .9 & $2.5^{* *}$ & & -2.8 & $2.3^{*}$ \\
\hline ICRG Country Risk & $-1.2^{*}$ & $(.8)$ & $. .8)$ & $(.6)$ & & $(1.7)$ & $(.9)$ \\
(Higher=Better) & $(.6)$ & $(.4)$ & -.4 & -.0 & & $-2.7^{* *}$ & .08 \\
\hline IMD Competitiveness & $3.8^{* *}$ & .9 & 1.6 & 1.2 & & $4.8^{* *}$ & -.2 \\
(Lower=Better) & $(1.0)$ & $(1.4)$ & $(1.5)$ & $(1.1)$ & & $(1.7)$ & $(1.6)$ \\
\hline WEF Competitiveness & 2.3 & .3 & .9 & .0 & & 3.7 & -.2 \\
(Lower=Better) & $(1.2)$ & $(1.1)$ & $(1.0)$ & $(.8)$ & & $(2.1)$ & $(1.1)$ \\
\hline Economic Security Index & $-.03^{*}$ & $-.02^{*}$ & $-.02^{*}$ & -.00 & & -.03 & -.00 \\
(Higher=More Secure) & $(.01)$ & $(.01)$ & $(.01)$ & $(.01)$ & & $(.02)$ & $(.01)$ \\
\hline Domestic Bank Credit, & $3.79^{* *}$ & $4.75^{* *}$ & $3.61^{* *}$ & $6.15^{* *}$ & $-38.7^{* *}$ & .11 & 6.0 \\
\%GDP & $(.96)$ & $(1.32)$ & $(1.20)$ & $(1.81)$ & $(13.1)$ & $(1.79)$ & $(3.2)$ \\
\hline Quasi-Liquid Liabilities, & $-1.44^{*}$ & .62 & .24 & 1.86 & -15.9 & $-5.9^{* *}$ & -2.2 \\
\%GDP & $(.62)$ & $(.74)$ & $(.70)$ & $(1.00)$ & $(9.5)$ & $(1.6)$ & $(2.4)$ \\
\hline M3, \% GDP & -.67 & .81 & .61 & $2.55^{*}$ & -10.7 & $-6.1 * *$ & -1.6 \\
& $(.74)$ & $(.85)$ & $(.80)$ & $(1.12)$ & $(8.9)$ & $(2.0)$ & $(2.6)$ \\
\hline
\end{tabular}

Panel F: Heterogeneity

\begin{tabular}{|r|c|c|c|c|c|c|}
\hline $\begin{array}{r}\text { Dependent } \\
\text { Variable }\end{array}$ & Bivariate & $\begin{array}{c}\text { Controls, } \\
\text { Set 1 }\end{array}$ & $\begin{array}{c}\text { Controls, } \\
\text { Set 2 }\end{array}$ & $\begin{array}{c}\text { Controls, } \\
\text { Set 3 }\end{array}$ & IV & $\begin{array}{c}\text { IV with } \\
\text { Controls }\end{array}$ \\
\hline $\begin{array}{r}\text { Ethnic Fractionalization } \\
\text { (High=Fractionalized) }\end{array}$ & .01 & -.00 & .00 & -.02 & $.03^{* *}$ & .01 \\
Ethnic Polarization & $-.005^{* *}$ & $(.01)$ & $(.01)$ & $(.01)$ & $(.01)$ & $(.03)$ \\
(High=Polarized) & $(.002)$ & $(.002)$ & -.004 & -.01 & -.002 & -.002 \\
\hline Ethno-Linguistic Fractional'n & 1.2 & 1.4 & 2.2 & -.8 & $6.4 * *$ & 1.4 \\
(High=Fractional) & $(1.2)$ & $(1.2)$ & $(1.4)$ & $(1.8)$ & $(1.6)$ & $(3.6)$ \\
\hline Linguistic Diversity & $.02^{* *}$ & .01 & .02 & -.01 & $.04 * *$ & .02 \\
(High=Diverse) & $(.01)$ & $(.01)$ & $(.01)$ & $(.02)$ & $(.01)$ & $(.03)$ \\
\hline Linguistic Fractionalization & .01 & .00 & .01 & -.01 & .018 & .01 \\
(High=Fractional) & $(.01)$ & $(.01)$ & $(.01)$ & $(.01)$ & $(.011)$ & $(.03)$ \\
\hline Geographic Dispersion & .01 & .01 & .02 & -.00 & $.078^{* *}$ & $.08^{* *}$ \\
(High=Dispersed) & $(.01)$ & $(.01)$ & $(.01)$ & $(.01)$ & $. .015)$ & $(.02)$ \\
\hline Religious Fractional'n (CH) & .25 & $2.4 *$ & 2.4 & .8 & .65 & 2.6 \\
(High=Fractional) & $(.88)$ & $(1.2)$ & $(1.3)$ & $(1.8)$ & $(1.25)$ & $(3.0)$ \\
\hline Religious Fractionalization & -.01 & .02 & $.02^{*}$ & .02 & -.01 & .02 \\
(ADEKW) (High=Fractional) & $(.01)$ & $(.01)$ & $(.01)$ & $(.01)$ & $(.01)$ & $(.02)$ \\
\hline Gini Coefficient & -.29 & .36 & .70 & .38 & $2.53^{*}$ & 1.42 \\
(High=Unequal) & $(.68)$ & $(.60)$ & $(.65)$ & $.74)$ & $(1.04)$ & $(1.10)$ \\
\hline
\end{tabular}

Slope coefficient for log of country population; robust standard errors (clustered by countries, where appropriate) in parentheses. Intercept/year effects are included but not recorded. * (**) indicates significantly different from zero at the .05 (.01) level. OLS estimates unless noted. Controls set \#1 (20 variables) includes: urbanization rate, density rate, and dummy variables for "countries" that are a) landlocked, island dummy, log of latitude (kilometers from equator), regional dummies for developing countries from Latin America, Sub-Saharan Africa, East Asia, South Asia, Europe-Central Asia, Middle East-North Africa, High Income country dummy, and language dummies for English, French, German, Dutch, Portuguese, Spanish, Arabic, Chinese. Controls set \#2 (25 variables) includes all controls in 1 plus: dummies for post-WW2 country, $(1800,1945)$ country, and dependencies, OPEC members, and COMECON members. Controls set \#3 (27 variables) includes all controls in sets 2 (and 1) plus: log real GDP per capita in \$; and proportion of land within $100 \mathrm{~km}$ of ice-free coastline or navigable river. Income is excluded as a control in income equations Fixed effects adds country-specific fixed effects. IV uses log of total area as instrumental variable for $\log$ population. IV with controls refers to controls set \#3 without density. 


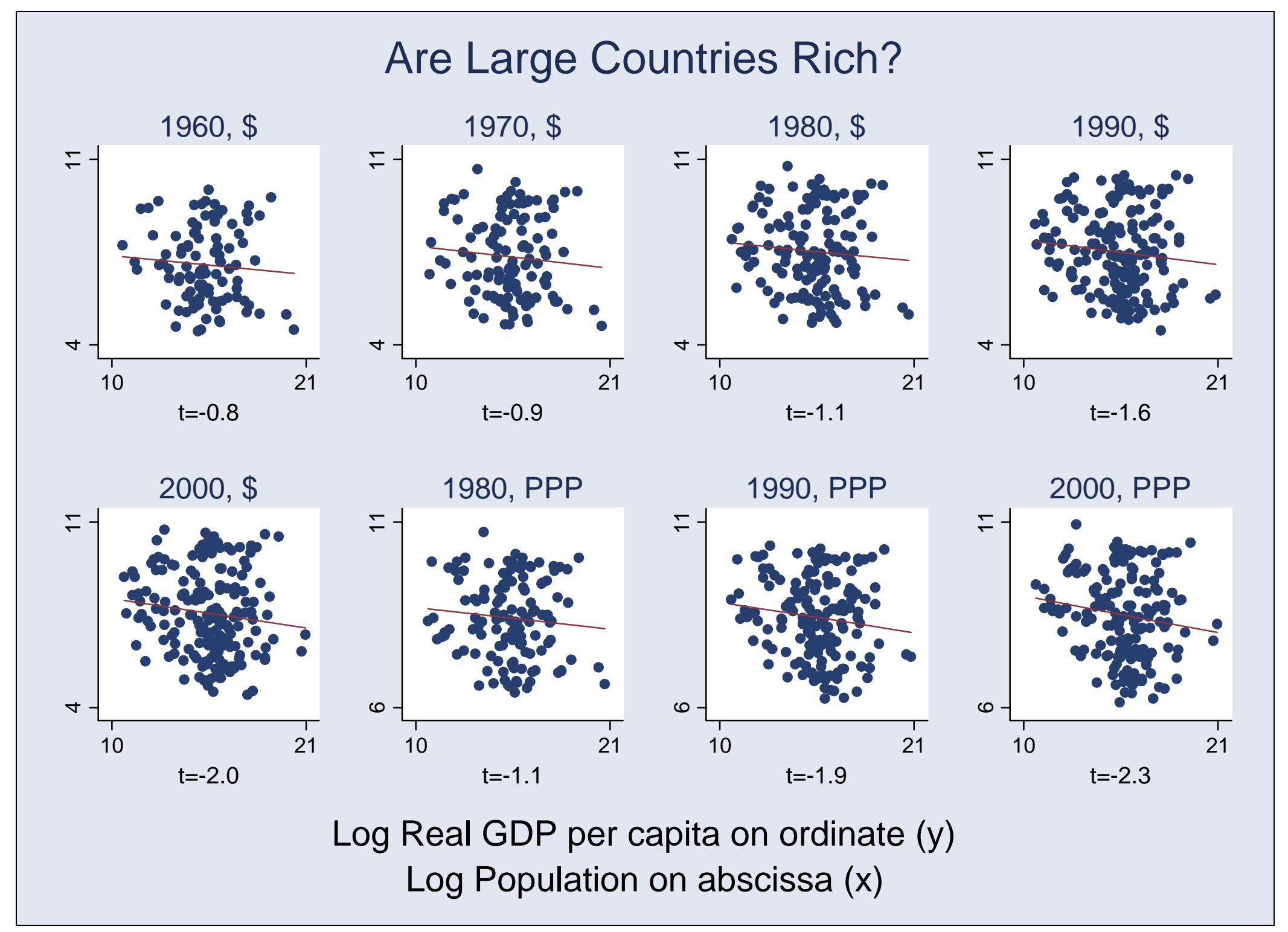

Figure 1: Income and Country Size 


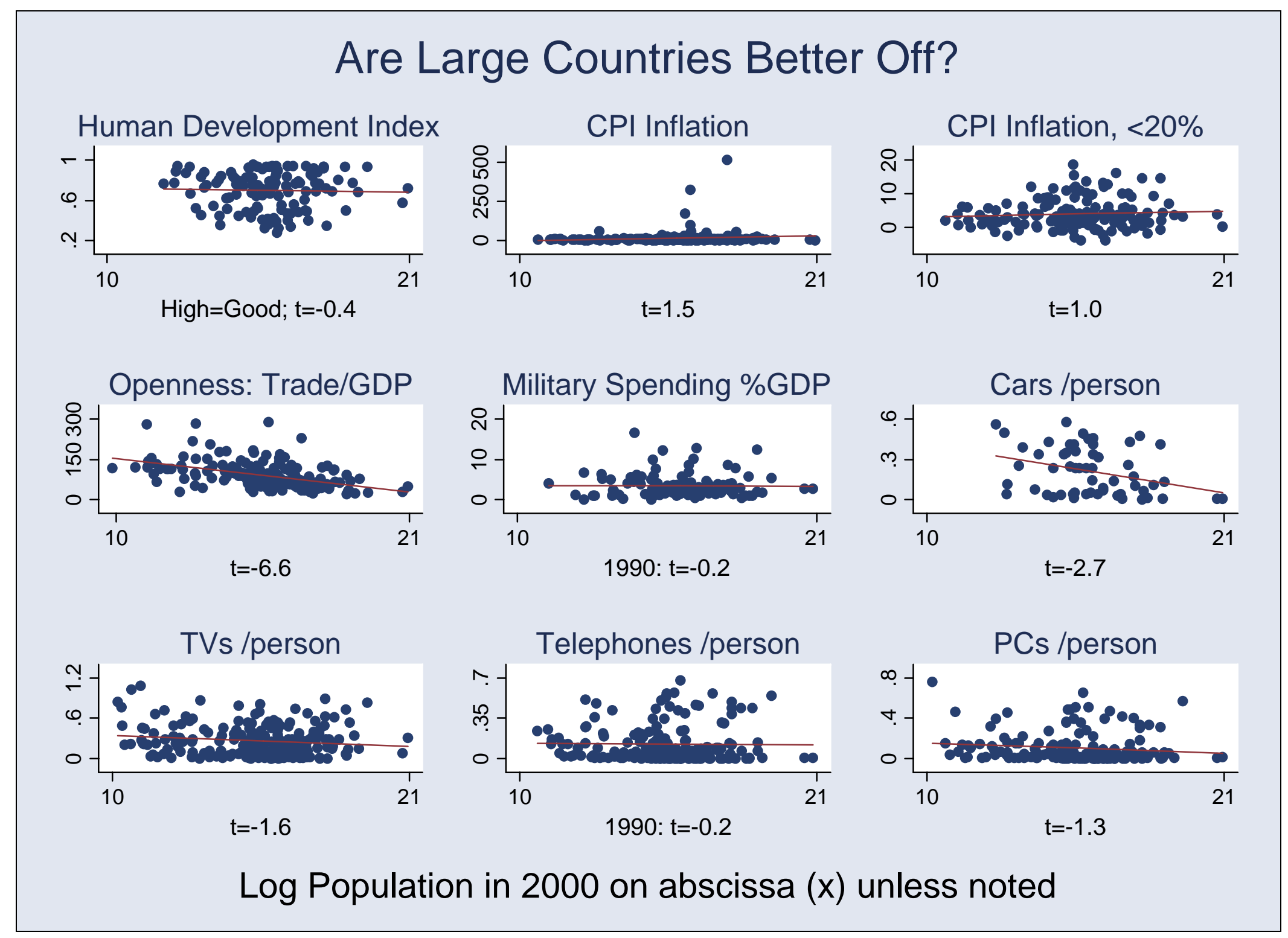

Figure 2: Economic Indicators and Country Size 


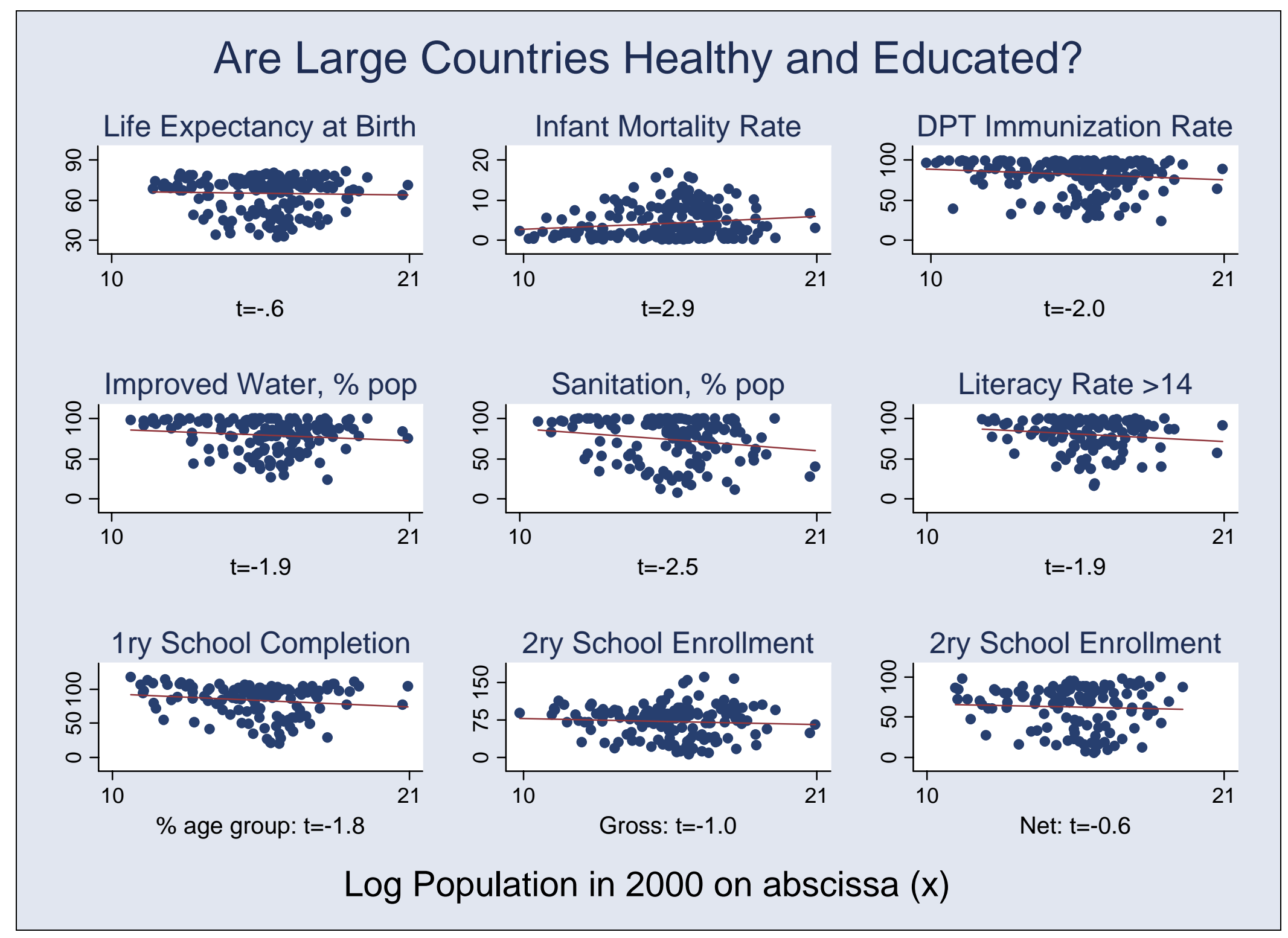

Figure 3: Health, Education, and Country Size 


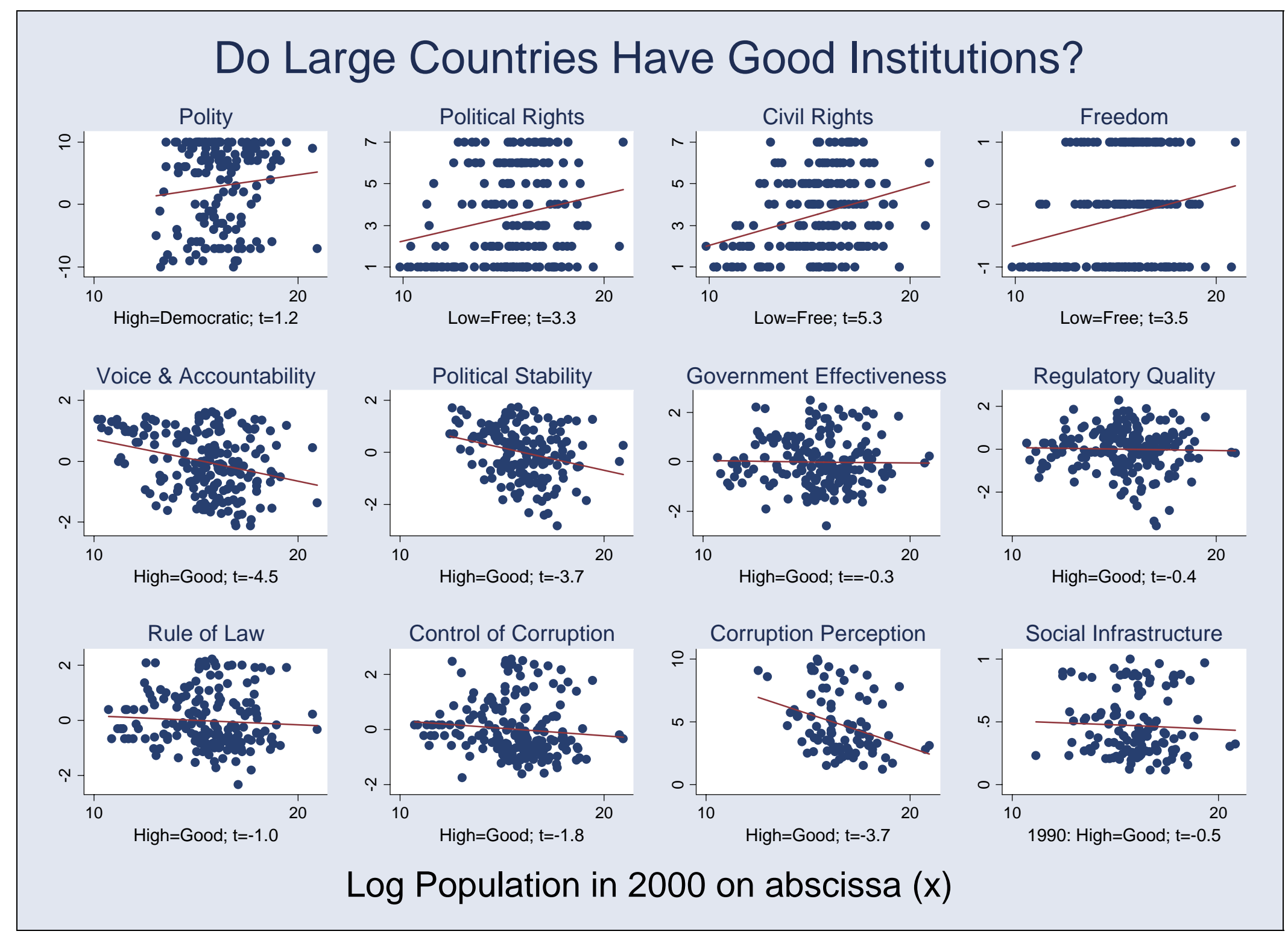

Figure 4: Institutions and Country Size 


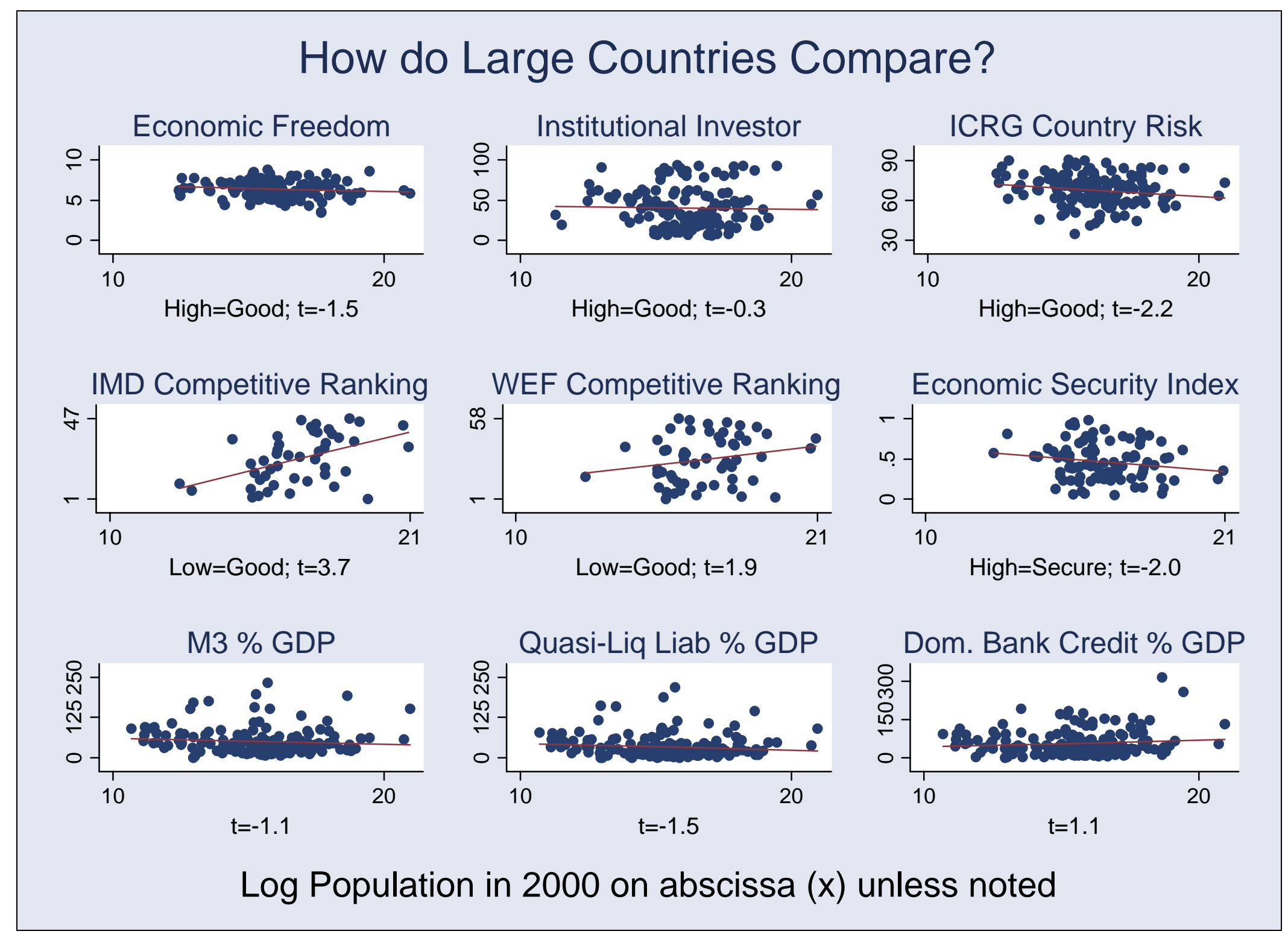

Figure 5: Rankings, Financial Depth, and Country Size 


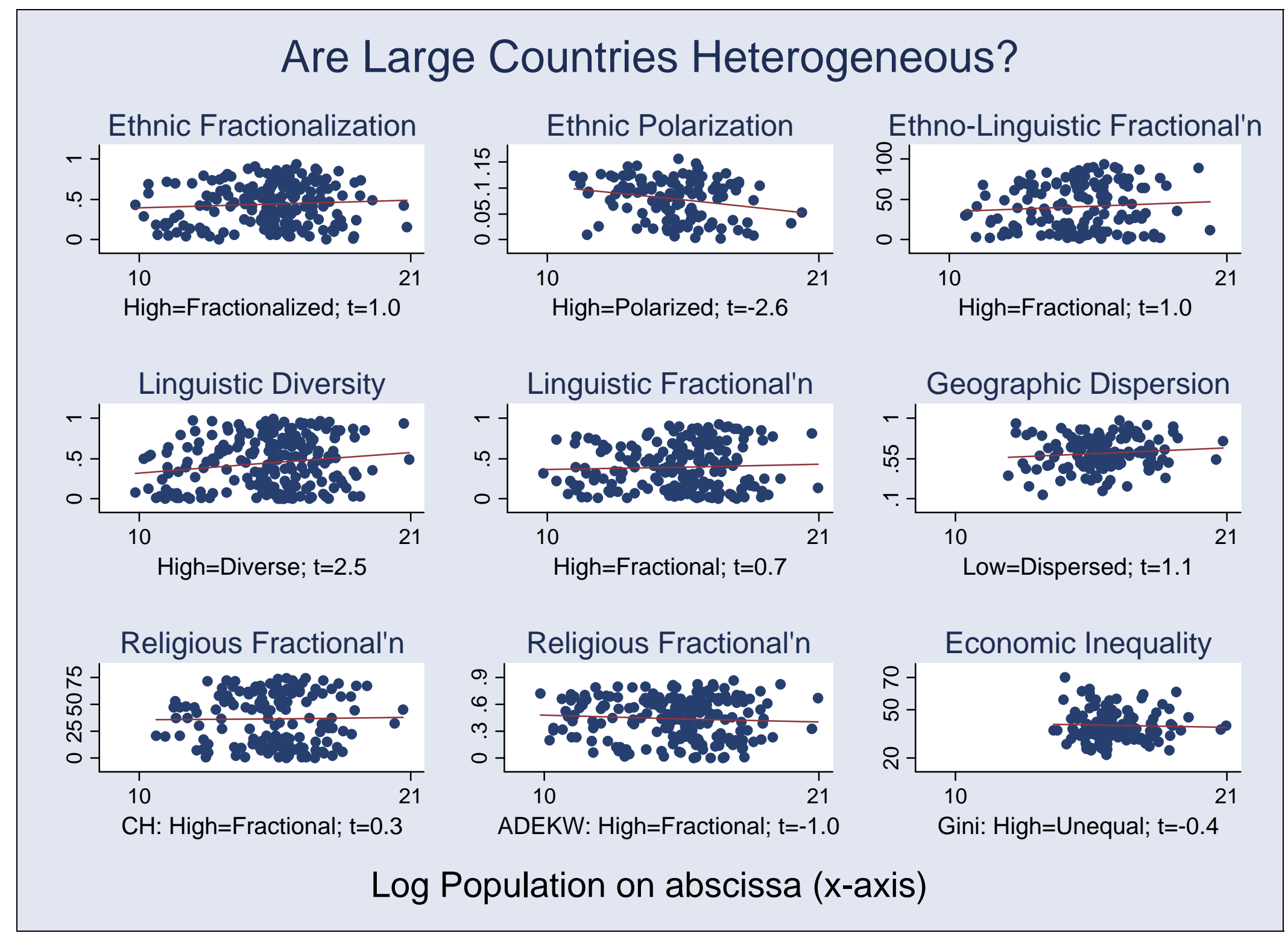

Figure 6: Heterogeneity and Country Size 
Appendix Table A1: List of “Countries"

\begin{tabular}{|c|}
\hline Afghanistan \\
\hline Albania \\
\hline Algeria \\
\hline American Samoa \\
\hline Andorra \\
\hline Angola \\
\hline Antigua and Barbuda \\
\hline Argentina \\
\hline Armenia \\
\hline Aruba \\
\hline Australia \\
\hline Austria \\
\hline Azerbaijan \\
\hline Bahamas, The \\
\hline Bahrain \\
\hline Bangladesh \\
\hline Barbados \\
\hline Belarus \\
\hline Belgium \\
\hline Belize \\
\hline Benin \\
\hline Bermuda \\
\hline Bhutan \\
\hline Bolivia \\
\hline Bosnia-Herzegovina \\
\hline Botswana \\
\hline Brazil \\
\hline Brunei \\
\hline Bulgaria \\
\hline Burkina Faso \\
\hline Burundi \\
\hline Cambodia \\
\hline Cameroon \\
\hline Canada \\
\hline Cape Verde \\
\hline Cayman Islands \\
\hline Central African Rep. \\
\hline Chad \\
\hline Channel Islands \\
\hline Chile \\
\hline China \\
\hline Colombia \\
\hline Comoros \\
\hline Congo, Dem. Rep. \\
\hline Congo, Rep. \\
\hline Costa Rica \\
\hline Cote d'Ivoire \\
\hline Croatia \\
\hline Cuba \\
\hline Cyprus \\
\hline Czech Republic \\
\hline Denmark \\
\hline Djibouti \\
\hline Dominica \\
\hline
\end{tabular}

\begin{tabular}{|c|}
\hline Dominican Republic \\
\hline Ecuador \\
\hline Egypt, Arab Rep. \\
\hline El Salvador \\
\hline Equatorial Guinea \\
\hline Eritrea \\
\hline Estonia \\
\hline Ethiopia \\
\hline Faeroe Islands \\
\hline Fiji \\
\hline Finland \\
\hline France \\
\hline French Polynesia \\
\hline Gabon \\
\hline Gambia, The \\
\hline Georgia \\
\hline Germany \\
\hline Ghana \\
\hline Greece \\
\hline Greenland \\
\hline Grenada \\
\hline Guam \\
\hline Guatemala \\
\hline Guinea \\
\hline Guinea-Bissau \\
\hline Guyana \\
\hline Haiti \\
\hline Honduras \\
\hline Hong Kong, China \\
\hline Hungary \\
\hline Iceland \\
\hline India \\
\hline Indonesia \\
\hline Iran, Islamic Rep. \\
\hline Iraq \\
\hline Ireland \\
\hline Isle of Man \\
\hline Israel \\
\hline Italy \\
\hline Jamaica \\
\hline Japan \\
\hline Jordan \\
\hline Kazakhstan \\
\hline Kenya \\
\hline Kiribati \\
\hline Korea, Dem. Rep. \\
\hline Korea, Rep. \\
\hline Kuwait \\
\hline Kyrgyz Republic \\
\hline Lao PDR \\
\hline Latvia \\
\hline Lebanon \\
\hline Lesotho \\
\hline Liberia \\
\hline
\end{tabular}

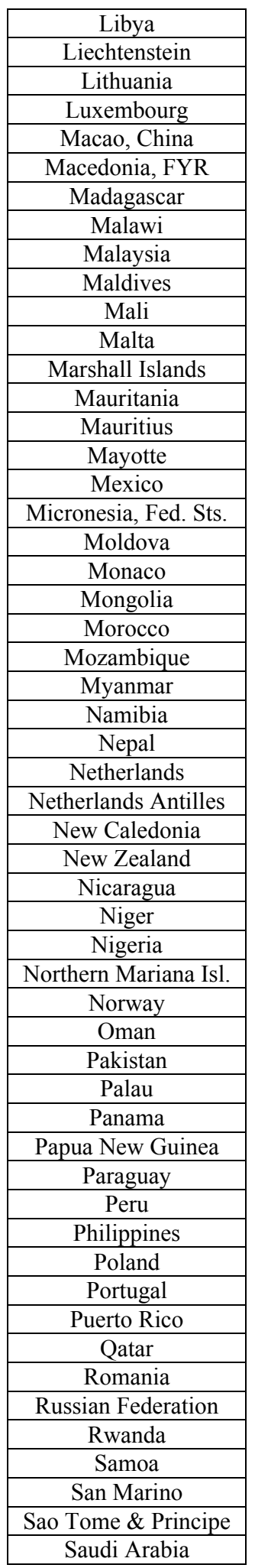

\begin{tabular}{|c|}
\hline Senegal \\
\hline Serbia \& Montenegro \\
\hline Seychelles \\
\hline Sierra Leone \\
\hline Singapore \\
\hline Slovak Republic \\
\hline Slovenia \\
\hline Solomon Islands \\
\hline Somalia \\
\hline South Africa \\
\hline Spain \\
\hline Sri Lanka \\
\hline St. Kitts and Nevis \\
\hline St. Lucia \\
\hline St. Vincent \& Gren. \\
\hline Sudan \\
\hline Suriname \\
\hline Swaziland \\
\hline Sweden \\
\hline Switzerland \\
\hline Syrian Arab Republic \\
\hline Tajikistan \\
\hline Tanzania \\
\hline Thailand \\
\hline Timor-Leste \\
\hline Togo \\
\hline Tonga \\
\hline Trinidad and Tobago \\
\hline Tunisia \\
\hline Turkey \\
\hline Turkmenistan \\
\hline Uganda \\
\hline Ukraine \\
\hline United Arab Emirates \\
\hline United Kingdom \\
\hline United States \\
\hline Uruguay \\
\hline Uzbekistan \\
\hline Vanuatu \\
\hline Venezuela, RB \\
\hline Vietnam \\
\hline Virgin Islands (U.S.) \\
\hline West Bank and Gaza \\
\hline Yemen, Rep. \\
\hline Zambia \\
\hline Zimbabwe \\
\hline
\end{tabular}




\section{Appendix Table A2: Data Sources}

- World Development Indicators (http://www.worldbank.org/data/wdi2005/index.html): population; real GDP per capita; inflation; trade openness; military spending; cars; televisions; telephones; personal computers; infant mortality; DPT Immunization rate; access to sanitation; literacy rate; primary school completion rate; gross and net secondary school enrollment rates; domestic bank credit; quasi-liquid liabilities; M3; density; urbanization; high-income and regional groupings.

- CIA World Factbook (http://www.cia.gov/cia/publications/factbook/): independence date; Gini coefficient; geographic and linguistic controls.

- UNDP (http://hdr.undp.org/statistics/data/): human development index; life expectancy at birth; access to improved water.

- KKZ (http://www1.worldbank.org/publicsector/indicators.htm): voice and accountability; political stability; government effectiveness; regulatory quality; rule of law; control of corruption.

- Collier-Hoeffler (http://users.ox.ac.uk/ ball0144/g\&g.zip): ethnic fractionalization; ethnic polarization; geographic dispersion; religious fractionalization.

- Alesina et al (2003) (http://www.stanford.edu/ wacziarg/downloads/fractionalization.xls): ethnic fractionalization; linguistic fractionalization; religious fractionalization.

- Freedom House (http://www.freedomhouse.org/): political and civil rights; freedom.

- Polity IV (http://www.cidem.umd.edu/inscr/polity/): polity.

- Gallup, Sachs and Messinger (http://www.ciesin.columbia.edu/data): proportion of land close to navigation.

- Transparency International (http://www.icgg.org/overview.csv): perception of corruption.

- Hall and Jones (http://emlab.berkeley.edu/users/chad/datasets.html): social infrastructure.

- Heritage Foundation (http://www.heritage.org/research/features/index/index.cfm): index of economic freedom.

- ICRG (http://www.prsgroup.com/icrg/icrg.html): country risk.

- $\operatorname{ILO}$ (http://www.ilo.org/public/english/protection/ses/download/docs/definition.pdf): economic security index.

- Ethnologue (http://www.ethnologue.com/ethno_docs/contents.asp): linguistic fractionalization.

- IMD (The World Competitiveness Yearbook 2000 p25): country overall ranking.

- WEF (The Global Competitiveness Report 2000 Table 1, p44): CCI ranking.

- Institutional Investor magazine (Institutional Investor March 2000 pp150-1): credit rating. 
Appendix Table A3: Descriptive Statistics for Key Variables

\begin{tabular}{|l|c|c|c|c|c|}
\hline & Obs. & Mean & $\begin{array}{c}\text { Std. } \\
\text { Dev, }\end{array}$ & Min & Max \\
\hline Log Population & 1040 & 14.75 & 2.32 & 8.94 & 20.96 \\
\hline Log real GDP per capita, \$ & 712 & 7.43 & 1.53 & 4.48 & 10.75 \\
\hline Log real GDP per capita, PPP & 458 & 8.45 & 1.11 & 6.13 & 10.94 \\
\hline Human Development Index & 367 & .67 & .19 & .256 & .95 \\
\hline CPI Inflation & 504 & 55.8 & 499.8 & -5.3 & 7485. \\
\hline Trade Openness & 671 & 73.3 & 44.8 & 3.7 & 287.4 \\
\hline Life Expectancy at Birth & 344 & 61.8 & 12.6 & 32.4 & 81.6 \\
\hline Infant Mortality Rate & 872 & 6.9 & 5.4 & .3 & 28.5 \\
\hline Literacy Rate & 477 & 69.1 & 26.1 & 5.7 & 99.8 \\
\hline Primary School Completion Rate & 202 & 79.1 & 26.6 & 12 & 121 \\
\hline Polity & 630 & .1 & 7.6 & -10 & 10 \\
\hline Political Rights & 501 & 3.9 & 2.3 & 1 & 7 \\
\hline Civil Rights & 501 & 3.9 & 1.9 & 1 & 7 \\
\hline Voice and Accountability & 189 & -.0 & 1.0 & -2.1 & 1.6 \\
\hline Political Stability & 165 & -.0 & 1.0 & -2.8 & 1.7 \\
\hline Perceived Corruption & 197 & 5.1 & 2.6 & 0 & 10 \\
\hline Social Infrastructure & 126 & .5 & .3 & .1 & 1 \\
\hline Economic Freedom & 387 & 5.7 & 1.3 & 2.3 & 8.7 \\
\hline Institutional Investor Credit & 144 & 40.7 & 25.1 & 5.7 & 93.8 \\
\hline ICRG Country Risk & 139 & 67.9 & 11.7 & 34.8 & 90.8 \\
\hline Domestic Bank Credit & 592 & 48.4 & 41.3 & .0 & 317. \\
\hline Ethnic Fractionalization (ADEKW) & 186 & .44 & .26 & 0 & .93 \\
\hline Linguistic Fractionalization & 191 & .39 & .28 & .00 & .92 \\
\hline Geographic Dispersion & 132 & .61 & .18 & .15 & .97 \\
\hline Religious Fractionalization (ADEKW) & 203 & .44 & .23 & .00 & .86 \\
\hline Log Area & 1040 & 10.95 & 2.96 & .69 & 16.65 \\
\hline
\end{tabular}


Appendix Table A4: Sensitivity Analysis on Real GDP per capita

\begin{tabular}{|c|c|c|c|c|c|c|c|}
\hline & Bivariate & $\begin{array}{c}\text { Controls, } \\
\text { Set } 1\end{array}$ & $\begin{array}{c}\text { Controls, } \\
\text { Set } 2 \\
\end{array}$ & $\begin{array}{c}\text { Controls, } \\
\text { Set } 3\end{array}$ & $\begin{array}{c}\text { Fixed } \\
\text { Effects }\end{array}$ & IV & $\begin{array}{l}\text { IV with } \\
\text { Controls }\end{array}$ \\
\hline Default & $\begin{array}{l}-.08 \\
(.06)\end{array}$ & $\begin{array}{c}-.08 * * \\
(.03)\end{array}$ & $\begin{array}{l}-.12 * * \\
(.03)\end{array}$ & $\begin{array}{l}-.12 * * \\
(.04)\end{array}$ & $\begin{array}{c}-.62 * * \\
(.16)\end{array}$ & $\begin{array}{l}-.21 * * \\
(.07)\end{array}$ & $\begin{array}{l}-.06 \\
(.05)\end{array}$ \\
\hline $\begin{array}{r}\text { Drop Latin America } \\
\text { and Caribbean }\end{array}$ & $\begin{array}{l}-.03 \\
(.05)\end{array}$ & $\begin{array}{l}-.02 \\
(.08)\end{array}$ & $\begin{array}{l}-.02 \\
(.08)\end{array}$ & $\begin{array}{c}.14 \\
(.11)\end{array}$ & $\begin{array}{l}-.37 \\
(.28)\end{array}$ & $\begin{array}{l}-.07 \\
(.07)\end{array}$ & $\begin{array}{c}.18 \\
(.15)\end{array}$ \\
\hline $\begin{array}{r}\text { Drop Sub-Saharan } \\
\text { Africa }\end{array}$ & $\begin{array}{l}-.26^{*} \\
(.11)\end{array}$ & $\begin{array}{l}-.10 \\
(.07)\end{array}$ & $\begin{array}{l}-.10 \\
(.09)\end{array}$ & $\begin{array}{l}-.24 \\
(.12)\end{array}$ & $\begin{array}{l}-.48 \\
(.86)\end{array}$ & $\begin{array}{l}-.18 \\
(.15)\end{array}$ & $\begin{array}{l}-.22 \\
(.18)\end{array}$ \\
\hline $\begin{array}{r}\text { Drop East Asia } \\
\text { and Pacific } \\
\end{array}$ & $\begin{array}{l}-.11 * \\
(.04)\end{array}$ & $\begin{array}{l}-.09 * \\
(.03)\end{array}$ & $\begin{array}{l}-.05 \\
(.05) \\
\end{array}$ & $\begin{array}{l}-2.1 \\
(1.0) \\
\end{array}$ & $\begin{array}{c}-.86 \\
(1.10) \\
\end{array}$ & $\begin{array}{l}-.13 * \\
(.05)\end{array}$ & $\begin{array}{c}.11 \\
(.30) \\
\end{array}$ \\
\hline $\begin{array}{r}\text { Drop High } \\
\text { Income }\end{array}$ & $\begin{array}{c}.04 \\
(.05)\end{array}$ & $\begin{array}{c}.04 \\
(.05)\end{array}$ & $\begin{array}{c}.00 \\
(.04)\end{array}$ & $\begin{array}{l}-.04 \\
(.06)\end{array}$ & $\begin{array}{l}-.45 \\
(.40)\end{array}$ & $\begin{array}{l}.15^{*} \\
(.06)\end{array}$ & $\begin{array}{l}-.05 \\
(.08)\end{array}$ \\
\hline $\begin{array}{r}\text { Drop Low } \\
\text { Income }\end{array}$ & $\begin{array}{l}-.09 * \\
(.03)\end{array}$ & $\begin{array}{l}-.07 \\
(.04)\end{array}$ & $\begin{array}{l}-.07 \\
(.05)\end{array}$ & $\begin{array}{l}-.11 * \\
(.05)\end{array}$ & $\begin{array}{l}-.03 \\
(.62)\end{array}$ & $\begin{array}{l}-.03 \\
(.06)\end{array}$ & $\begin{array}{c}.02 \\
(.08)\end{array}$ \\
\hline $\begin{array}{r}\text { Drop Poor } \\
(\text { GDP p/c }<\$ 500)\end{array}$ & $\begin{array}{l}-.03 \\
(.02)\end{array}$ & $\begin{array}{l}-.05 \\
(.03)\end{array}$ & $\begin{array}{l}-.06^{*} \\
(.02)\end{array}$ & $\begin{array}{l}-.11 * * \\
(.03)\end{array}$ & $\begin{array}{l}-1.08 \\
(.94)\end{array}$ & $\begin{array}{l}-.02 \\
(.04)\end{array}$ & $\begin{array}{c}.01 \\
(.06)\end{array}$ \\
\hline $\begin{array}{r}\text { Drop Rich } \\
(\text { GDP p/c }>\$ 15,000) \\
\end{array}$ & $\begin{array}{l}-.02 \\
(.03)\end{array}$ & $\begin{array}{c}.01 \\
(.04) \\
\end{array}$ & $\begin{array}{l}-.05 \\
(.06) \\
\end{array}$ & $\begin{array}{l}-.10 \\
(.08)\end{array}$ & $\begin{array}{c}-1.25 * * \\
(.25) \\
\end{array}$ & $\begin{array}{l}-.01 \\
(.03) \\
\end{array}$ & $\begin{array}{l}-.04 \\
(.05)\end{array}$ \\
\hline $\begin{array}{r}\text { Drop Small } \\
(\text { Pop. }<100,000)\end{array}$ & $\begin{array}{l}-.09 \\
(.07)\end{array}$ & $\begin{array}{l}-.07 * \\
(.03)\end{array}$ & $\begin{array}{c}-.11 * * \\
(.03)\end{array}$ & $\begin{array}{l}-.12 * * \\
(.04)\end{array}$ & $\begin{array}{c}-.60 * * \\
(.17)\end{array}$ & $\begin{array}{l}-.25 * * \\
(.09)\end{array}$ & $\begin{array}{l}-.06 \\
(.05)\end{array}$ \\
\hline $\begin{array}{r}\text { Drop Large } \\
\text { (Pop.>100,000,000) }\end{array}$ & $\begin{array}{l}-.08 \\
(.06)\end{array}$ & $\begin{array}{l}-.10 * * \\
(.03)\end{array}$ & $\begin{array}{c}-.14 * * \\
(03)\end{array}$ & $\begin{array}{c}-.15 * * \\
(.04)\end{array}$ & $\begin{array}{c}-.60 * * \\
(.17)\end{array}$ & $\begin{array}{c}-.24 * * \\
(.08)\end{array}$ & $\begin{array}{l}-.08 \\
(.06)\end{array}$ \\
\hline
\end{tabular}

Slope coefficient for log of country population; robust standard errors (clustered by countries, where appropriate) in parentheses. Intercept/year effects are included but not recorded. $*(* *)$ indicates significantly different from zero at the .05 (.01) level. Regressand is log real GDP per capita in \$.

OLS estimates unless noted. Controls set \#1 (20 variables) includes: urbanization rate, density rate, and dummy variables for "countries" that are a) landlocked, island dummy, log of latitude (kilometers from equator), regional dummies for developing countries from Latin America, Sub-Saharan Africa, East Asia, South Asia, Europe-Central Asia, Middle East-North Africa, High Income country dummy, and language dummies for English, French, German, Dutch, Portuguese, Spanish, Arabic, Chinese.

Controls set \#2 (25 variables) includes all controls in 1 plus: dummies for post-WW2 country, $(1800,1945)$ country, and dependencies, OPEC members, and COMECON members. Controls set \#3 (27 variables) includes all controls in sets 2 (and 1) plus proportion of land within $100 \mathrm{~km}$ of ice-free coastline or navigable river. Income is excluded as a control in income equations Fixed effects adds country-specific fixed effects. IV uses log of total area as instrumental variable for $\log$ population. IV with controls refers to controls set \#3 without density. 


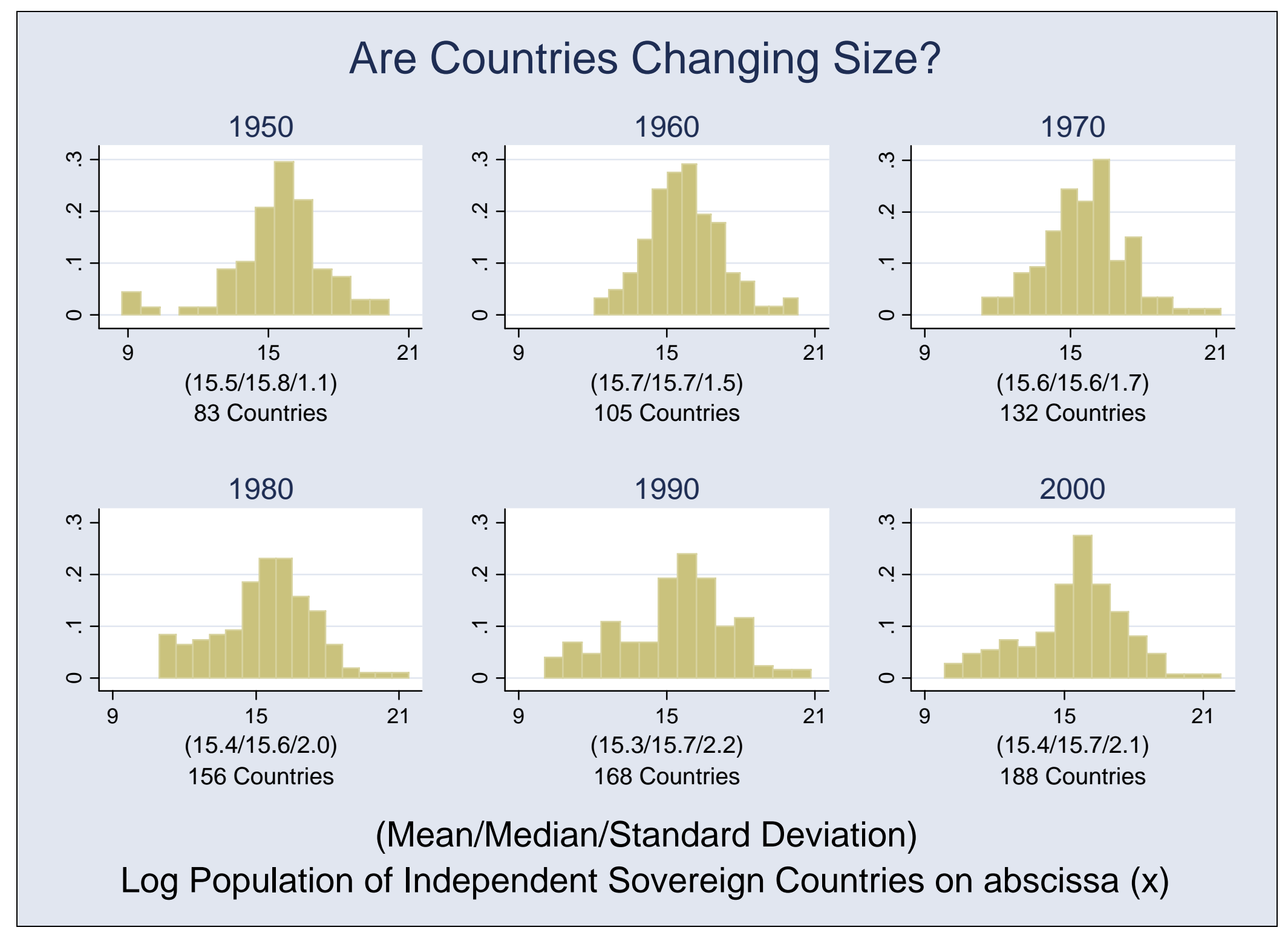

Figure A1: Histograms of Country Size over Time 


\section{Endnotes}

${ }^{1}$ Using data from the CIA's World Factbook, http://www.cia.gov/cia/publications/factbook/

${ }^{2}$ This has been noted since at least Dahle and Tufte (1973).

${ }^{3}$ On the other hand, it may also be unexpected. Plato thought there was an optimal state size; more on this later. In 1984 George Orwell described a world with three giant states of approximately equal size.

${ }^{4}$ In passing, I note that the models AS develop are symmetric by assumption, and are not designed to deliver heterogeneously sized countries.

${ }^{5}$ Drazen (2000) provides an excellent critique, and emphasizes (among other things) that public goods can be supplied by clubs instead of countries.

${ }^{6}$ It is interesting to note that Plato's logic was that 5,040 is divisible by all numbers 1 through 10. Indeed, 5,040 is a colossally abundant number; its factorization is $2^{2 *} 3^{2} * 5 * 7$;

http://mathworld.wolfram.com/ColossallyAbundantNumber.html

${ }^{7}$ Jean Jacques Rousseau in The Government of Poland quoted at

http://www.brothersjudd.com/blog/archives/010141.html.

${ }^{8}$ De l'Esprit des Lois Vol I, Book 8, p 131.

${ }^{9}$ There is also a modern strain of political thought which argues that larger countries are inferior; E.F. Schumacher and especially Leopold Kohr (especially in The Breakdown of Nations) are among the more well-known writers.

${ }^{10}$ The main focus of Alesina, Spolaore and Waczairg (2000) is to check that both openness and size have a positive effect growth of real income, while the interaction between openness and size has a negative effect. They also find weaker evidence showing similar results for the level of real income. When I use my data set (which includes more countries sampled at longer intervals) to examine the determinants of real income levels, I find similar results that are statistically insignificant using the log of population to measure size.

${ }^{11} \mathrm{http}: / / \mathrm{www} . c i a . g o v / \mathrm{cia} /$ publications/factbook/

${ }^{12}$ The correspondence is imperfect for both definitions. Labor is mobile between countries over long periods of time. Dependencies do not have a complete monopoly over legal coercion (though since mother countries rarely exercise their rights, it is typically a de facto near-complete monopoly); neither do sovereign nation states (think of the Korean or first Gulf wars). Other definitions of a country include the "Westphalian state" (an entity that enjoys extensive autonomy in its domestic economic and social policy, largely free from interference from other states and powers) and that taken from the 1933 Montevideo Convention (the state as a person of international law should possess the following qualifications: (a) a permanent population; (b) a defined territory; (c) government; and (d) capacity to enter into relations with the other states); see http://www.nationmaster.com/encyclopedia/State.

${ }^{13}$ I focus on outcomes rather than inputs such as spending; AS provide some evidence on the latter.

${ }^{14}$ Dahl and Tufte (1973, p17) state "Most discussions of the relation between size and popular government use population as their criterion of size ..." I note in passing that in 2000 , the correlation between the natural logarithms of countries' surface areas and populations was .84 .

15 The observations for some variables were collected at different points of time (sometimes not around the years for which I have population data), which may be an issue. Further, I only use data at decadal intervals, another potential problem. I do not consider either issue to be of overwhelming importance, since my variables tend to be quite persistent, but it may be worth pursuing.

${ }^{16}$ It is hard to describe the HDI precisely is. The UNDP states (http://hdr.undp.org/hd/glossary.cfm), "Human development is a process of enlarging people's choices. Enlarging people's choices is achieved by expanding human capabilities and functionings. At all levels of development the three essential capabilities for human development are for people to lead long and healthy lives, to be knowledgeable and to have a decent standard of living. If these basic capabilities are not achieved, many choices are simply not available and many opportunities remain inaccessible. But the realm of human development goes further: essential areas of choice, highly valued by people, range from political, economic and social opportunities for being creative and productive to enjoying self-respect, empowerment and a sense of belonging to a community. The concept of human development is a holistic one putting people at the centre of all aspects of the development process."

${ }^{17}$ The eleven countries with recorded annual CPI inflation exceeding 20\% in 2000 are: Angola, Belarus, Burundi, Congo (Dem. Rep.), Ecuador, Ghana, Laos, Malawi, Moldova, Romania, Russia, Suriname, Turkey, Ukraine, Zambia, and Zimbabwe.

${ }^{18}$ Openness is taken from the WDI, as are most of the other series mentioned below unless explicitly noted otherwise. 
${ }^{19}$ It would be natural and interesting to compare crime rates across countries. The key issue here is the fact that different jurisdictions collect crime data in incompatible ways; in 2000, the UN data set indicates that the country with the lowest crime rate was Pakistan with a rate of 2.23/100,000 inhabitants (the second-highest crime rate was Sweden in 1990 with 14,240); see www.unodc.org. A simple regression of the crime rate against the log of population delivers a negative effect of country size on the crime rate if one controls for year effects, but a positive effect if one controls for country effects.

${ }^{20}$ The Polity IV project is available at http://www.cidcm.umd.edu/inscr/polity/

${ }^{21} \mathrm{http}: / /$ www.freedomhouse.org/

${ }^{22}$ The KKZ data on aggregate governance indicators are available from the World Bank's website at http://www1.worldbank.org/publicsector/indicators.htm, while the Transparency International corruption perceptions index is available at http://www.icgg.org/overview.csv

${ }^{23}$ On the ESI, the ILO states "We propose that it is the combination of securities that make up economic security, and that this constitutes a decent work environment... In a sense, decent work can be said to exist when individuals have a decent level of income security, decent representation security, decent work security, and the real freedom to pursue whatever of the other forms of work-related securities they desire.... Economic security is measured as a combination of the normalized values of the seven socio-economic security indexes to yield a composite measure designated the Economic Security Index (ESI). The ESI is defined as a weighted average of the scores of the seven forms of security, in which double weight is given to income security and to representation security, for reasons that basic income security is essential for real freedom to make choices and that representation security is essential to enable the vulnerable to retain income security. The ILO provides definitions of "economic security" at http://www.ilo.org/public/english/protection/ses/download/docs/definition.pdf.

${ }^{24}$ The WDI defines the latter two as follows:

"Quasi-liquid liabilities are the sum of currency and deposits in the central bank (M0), plus time and savings deposits, foreign currency transferable deposits, certificates of deposit, and securities repurchase agreements, plus travelers checks, foreign currency time deposits, commercial paper, and shares of mutual funds or market funds held by residents. They equal the M3 money supply less transferable deposits and electronic currency (M1)." "Domestic credit provided by the banking sector includes all credit to various sectors on a gross basis, with the exception of credit to the central government, which is net. The banking sector includes monetary authorities and deposit money banks, as well as other banking institutions where data are available (including institutions that do not accept transferable deposits but do incur such liabilities as time and savings deposits). Examples of other banking institutions are savings and mortgage loan institutions and building and loan associations."

${ }^{25}$ Perhaps the most striking feature of the figure is the cross-country diversity in domestic diversity, not the fact that the variation is not closely linked to country size.

${ }^{26}$ The first stage fits well; when I regress the log of population against the log of area (and time dummies), I get an $\mathrm{R}^{2}$ of .68 and a robust t-statistic on $\log$ area of 19 .

${ }^{27}$ Clearly the third set of controls cannot be added when the regressand is real GDP per capita. Also, since all the measures of heterogeneity are cross-sectional no fixed effects estimates are possible for Panel F.

${ }^{28}$ I have also substituted both the log of the labor force and the log of the population between ages 15 and 64 in place of the log of population. Neither alternative measure of country size leads to different conclusions.

${ }^{29}$ The UN data are available through www.unodc.org.

${ }^{30}$ Dahl and Tufte (1973, p 122) conclude “... a country's chances of survival do not depend significantly on its size." Preliminary work indicates that civil wars are increasing in country size. 
To order any of these papers in hard copy, see instructions at the end of this list. To subscribe to all NBER Working Papers or the papers in a single area, see instructions inside the back cover.

$\underline{\text { Number }}$

12130

12131

12132

12133

12134

12135

12136

12137

12138

12139

12140

12141

12142

12144

12145

12146 $\underline{\text { Author(s) }}$

Ellen R. McGrattan

Lee E. Ohanian

Johannes Van Biesebroeck

Tomas J. Philipson

Richard A. Posner

James A. Robinson

Ragnar Torvik

Li Gan

Qinghua Zhang

John G. Shoven

Sita N. Slavov

Ricardo J. Caballero

Arvind Krishnamurthy

Filippo Occhino

Kim Oosterlinck

Eugene N. White

Eugene N. White

Claudia Goldin

Lawrence F. Katz

Ilyana Kuziemko

Heinrich Hock

David N. Weil

Gordon H. Hanson

Charles Yuji Horioka

Jacob L. Vigdor

Jules H. van Binsbergen

Michael W. Brandt

Ralph S.J. Koijen

Justine S. Hastings

Thomas J. Kane

Douglas O. Staiger

Clemens Sialm
Title

$\underline{\text { Date }}$

Does Neoclassical Theory Account for the Effects of Big 3/06

Fiscal Shocks? Evidence From World War II

Complementarities in Automobile Production 3/06

Antitrust in the Not-For-Profit Sector 3/06

A Political Theory of the Soft Budget Constraint 3/06

The Thick Market Effect on Housing Markets Transactions 3/06

Political Risk versus Market Risk in Social Security $\quad 3 / 06$

Flight to Quality and Collective Risk Management 3/06

How Occupied France Financed Its Own Exploitation in 3/06 World War II

Bubbles and Busts: The 1990s in the Mirror of the 1920s 3/06

The Homecoming of American College Women: The 3/06

Reversal of the College Gender Gap

The Dynamics of Age Structure, Dependency, and 3/06 Consumption

Illegal Migration from Mexico to the United States $\quad 3 / 06$

The Causes of Japan's 'Lost Decade': The Role of 3/06 Household Consumption

The New Promised Land: Black-White Convergence in 3/06 The American South, 1960-2000

Optimal Decentralized Investment Management 3/06

Preferences and Heterogeneous Treatment Effects in a 3/06 Public School Choice Lottery

Investment Taxes and Equity Returns

$3 / 06$ 
To order any of these papers in hard copy, see instructions at the end of this list. To subscribe to all NBER Working Papers or the papers in a single area, see instructions inside the back cover.

$\underline{\text { Number }}$

12147

12148

12149

12150

12151

12152

12153

12155

12156

12157

12158

12159

12160

12161

12162 $\underline{\text { Author(s) }}$

David N. Weil

Stephen M. Maurer

Suzanne Scotchmer

John Y. Campbell

Elizabeth Oltmans Ananat

Jonathan Gruber

Phillip B. Levine

Douglas O. Staiger

Ravi Jagannathan

Ann E. Sherman

Steven D. Levitt

Enrico Spolaore

Romain Wacziarg

Sebastian Edwards

Thomas J. Kane

Jonah E. Rockoff

Douglas O. Staiger

Mark Coppejans

Donna Gilleskie

Holger Sieg

Koleman Strumpf

Paul Oyer

Pierpaolo Benigno

Michael Woodford

Phil Oreopoulos

Till von Wachter

Andrew Heisz

Douglas A. Irwin

Douglas A. Irwin

Douglas A. Irwin $\underline{\text { Title }}$

$\underline{\text { Date }}$

$\begin{array}{ll}\text { Population Aging } & 3 / 06\end{array}$

Open Source Software: The New Intellectual Property 3/06

Paradigm

$\begin{array}{ll}\text { Household Finance } & 3 / 06\end{array}$

Abortion and Selection 3/06

Why Do IPO Auctions Fail?

An Economist Sells Bagels: A Case Study in Profit $\quad 3 / 06$ Maximization

The Diffusion of Development

$3 / 06$

The U.S. Current Account Deficit: Gradual Correction or 3/06 Abrupt Adjustment?

What Does Certification Tell Us About Teacher

$4 / 06$

Effectiveness? Evidence from New York City

Consumer Demand Under Price Uncertainty: Empirical 4/06 Evidence from the Market for Cigarettes

The Macro-Foundations of Microeconomics: Initial Labor 4/06 Market Conditions and Long-Term Outcomes for Economists

Optimal Inflation Targeting Under Alternative Fiscal 4/06 Regimes

The Short- and Long-Term Career Effects of Graduating 4/06 in a Recession: Hysteresis and Heterogeneity in the Market for College Graduates

The Impact of Federation on Australia's Trade Flows 4/06

Antebellum Tariff Politics: Coalition Formation and 4/06 Shifting Regional Interests

Tariff Incidence in America's Gilded Age

$4 / 06$ 
To order any of these papers in hard copy, see instructions at the end of this list. To subscribe to all NBER Working Papers or the papers in a single area, see instructions inside the back cover.

\begin{tabular}{|c|c|c|c|}
\hline Number & $\underline{\text { Author(s) }}$ & $\underline{\text { Title }}$ & Date \\
\hline 12163 & Sebastian Edwards & $\begin{array}{l}\text { The Relationship Between Exchange Rates and Inflation } \\
\text { Targeting Revisited }\end{array}$ & $4 / 06$ \\
\hline 12164 & $\begin{array}{l}\text { Nathan Nunn } \\
\text { Daniel Trefler }\end{array}$ & $\begin{array}{l}\text { Putting the Lid on Lobbying: Tariff Structure and Long- } \\
\text { Term Growth When Protection is for Sale }\end{array}$ & $4 / 06$ \\
\hline 12165 & $\begin{array}{l}\text { Robert Engle } \\
\text { Robert Ferstenberg }\end{array}$ & Execution Risk & $4 / 06$ \\
\hline 12166 & $\begin{array}{l}\text { Gadi Barlevy } \\
\text { H.N. Nagaraja }\end{array}$ & $\begin{array}{l}\text { Identification of Search Models with Initial Condition } \\
\text { Problems }\end{array}$ & $4 / 06$ \\
\hline 12167 & $\begin{array}{l}\text { Steven J. Davis } \\
\text { R. Jason Faberman } \\
\text { John Haltiwanger }\end{array}$ & $\begin{array}{l}\text { The Flow Approach to Labor Markets: New Data Sources } \\
\text { and Micro-Macro Links }\end{array}$ & $4 / 06$ \\
\hline 12168 & Martin Feldstein & $\begin{array}{l}\text { The } 2006 \text { Economic Report of the President: Comment on } \\
\text { Chapter One (The Year in Review) and Chapter Six (The } \\
\text { Capital Account Surplus) }\end{array}$ & \\
\hline 12169 & $\begin{array}{l}\text { Stefano Della Vigna } \\
\text { Ethan Kaplan }\end{array}$ & The Fox News Effect: Media Bias and Voting & $4 / 06$ \\
\hline 12170 & Edward J. Kane & $\begin{array}{l}\text { Inadequacy of Nation-Based and VaR-Based Safety Nets } \\
\text { in the European Union }\end{array}$ & $4 / 06$ \\
\hline 12171 & $\begin{array}{l}\text { Janet Currie } \\
\text { Erdal Tekin }\end{array}$ & Does Child Abuse Cause Crime? & $4 / 06$ \\
\hline 12172 & $\begin{array}{l}\text { Lynne G. Zucker } \\
\text { Michael R. Darby }\end{array}$ & $\begin{array}{l}\text { Movement of Star Scientists and Engineers and High-Tech } \\
\text { Firm Entry }\end{array}$ & h 4/06 \\
\hline 12173 & Peter K. Schott & The Relative Sophistication of Chinese Exports & $4 / 06$ \\
\hline 12174 & Roland G. Fryer, Jr. & $\begin{array}{l}\text { Belief Flipping in a Dynamic Model of Statistical } \\
\text { Discrimination }\end{array}$ & $4 / 06$ \\
\hline 12175 & $\begin{array}{l}\text { Torsten Persson } \\
\text { Guido Tabellini }\end{array}$ & $\begin{array}{l}\text { Democratic Capital: The Nexus of Political and Economic } \\
\text { Change }\end{array}$ & c 4/06 \\
\hline 12176 & $\begin{array}{l}\text { Alan Manning } \\
\text { Jörn-Steffen Pischke }\end{array}$ & $\begin{array}{l}\text { Comprehensive versus Selective Schooling in England in } \\
\text { Wales: What Do We Know? }\end{array}$ & $4 / 06$ \\
\hline 12177 & $\begin{array}{l}\text { Florian Zettelmeyer } \\
\text { Fiona Scott Morton } \\
\text { Jorge Silva-Risso }\end{array}$ & $\begin{array}{l}\text { Scarcity Rents in Car Retailing: Evidence from Inventory } \\
\text { Fluctuations at Dealerships }\end{array}$ & $4 / 06$ \\
\hline 12178 & John Whalley & The Post MFA Performance of Developing Asia & $4 / 06$ \\
\hline 12179 & Elizabeth Cascio & Public Preschool and Maternal Labor Supply: Evidence & $4 / 06$ \\
\hline
\end{tabular}


To order any of these papers in hard copy, see instructions at the end of this list. To subscribe to all NBER Working Papers or the papers in a single area, see instructions inside the back cover.

\begin{tabular}{|c|c|c|c|}
\hline$\underline{\text { Number }}$ & $\underline{\text { Author(s) }}$ & $\underline{\text { Title }}$ & Date \\
\hline & & \multicolumn{2}{|c|}{$\begin{array}{l}\text { From the Introduction of Kindergartens into American Public } \\
\text { Schools }\end{array}$} \\
\hline 12180 & $\begin{array}{l}\text { Andreas Ammermueller } \\
\text { Jörn-Steffen Pischke }\end{array}$ & \multicolumn{2}{|c|}{$\begin{array}{l}\text { Peer Effects in European Primary Schools: Evidence from 4/06 } \\
\text { PIRLS }\end{array}$} \\
\hline 12181 & Sebnem Kalemli-Ozcan & $\begin{array}{l}\text { AIDS, Reversal of the Demographic Transition and } \\
\text { Economic Development: Evidence from Africa }\end{array}$ & $4 / 06$ \\
\hline 12182 & $\begin{array}{l}\text { Shane Greenstein } \\
\text { Jeff Prince }\end{array}$ & $\begin{array}{l}\text { The Diffusion of the Internet and the Geography of the } \\
\text { Digital Divide in the United States }\end{array}$ & $4 / 06$ \\
\hline 12183 & $\begin{array}{l}\text { Long Chen } \\
\text { Ralitsa Petkova } \\
\text { Lu Zhang }\end{array}$ & The Expected Value Premium & $4 / 06$ \\
\hline 12184 & $\begin{array}{l}\text { David M. Cutler } \\
\text { Mary Beth Landrum } \\
\text { Kate A. Stewart }\end{array}$ & $\begin{array}{l}\text { Intensive Medical Care and Cardiovascular Disease } \\
\text { Disability Reductions }\end{array}$ & $4 / 06$ \\
\hline 12185 & David W. Galenson & \multicolumn{2}{|c|}{$\begin{array}{l}\text { Analyzing Artistic Innovation: The Greatest Breakthroughs 4/06 } \\
\text { Of the Twentieth Century }\end{array}$} \\
\hline 12186 & $\begin{array}{l}\text { Anusha Chari } \\
\text { Peter Blair Henry }\end{array}$ & \multicolumn{2}{|c|}{ Firm-Specific Information and the Efficiency of Investment $4 / 06$} \\
\hline 12187 & $\begin{array}{l}\text { Serkan Arslanalp } \\
\text { Peter Blair Henry }\end{array}$ & Debt Relief & $4 / 06$ \\
\hline 12188 & $\begin{array}{l}\text { Marianne Baxter } \\
\text { Michael A. Kouparitsas }\end{array}$ & What Determines Bilateral Trade Flows? & $4 / 06$ \\
\hline 12189 & $\begin{array}{l}\text { Michael Bordo } \\
\text { Harold James }\end{array}$ & One World Money, Then and Now & $4 / 06$ \\
\hline 12190 & $\begin{array}{l}\text { Allan Drazen } \\
\text { Marcela Eslava }\end{array}$ & Pork Barrel Cycles & $4 / 06$ \\
\hline 12191 & Andrew K. Rose & $\begin{array}{l}\text { Size Really Doesn't Matter: In Search of a National Sca } \\
\text { Effect }\end{array}$ & e 4/06 \\
\hline
\end{tabular}

Copies of the above working papers can be obtained for $\$ 10.00$ per copy (plus $\$ 10.00$ per order for shipping for all locations outside the continental U.S.) to Working Papers, NBER, 1050 Massachusetts Avenue, Cambridge, MA 021385398. Pre-payment is required on all orders and may be made by check or credit card. Checks should be made payable to the NBER and must be in dollars drawn on a U.S. bank. If paying by credit card, include the cardholder's name, account number, and expiration date. For all orders, please be sure to include your return address and telephone number. Working papers may also be ordered by telephone (868-3900), fax (617-868-2742), or email (orders@nber.org). 